\title{
A review of crust and upper mantle structure beneath the India subcontinent
}

\author{
Arun Singh ${ }^{\mathrm{a}, *}$, Chandrani Singh ${ }^{\mathrm{a}}$, B. L. N. Kennett ${ }^{\mathrm{b}}$ \\ ${ }^{a}$ Department of Geology and Geophysics, \\ Indian Institute of Technology Kharagpur, India \\ ${ }^{b}$ Research School of Earth Sciences, \\ The Australian National University, Canberra ACT 2601, Australia
}

\section{Abstract}

9 This review presents an account of the variations in crustal and upper mantle structure beneath the Indian subcontinent and its environs, with emphasis on passive seismic results supplemented by results using controlled seismic sources. Receiver function results 12 from more than 600 seismic stations, and over 10,000 km of deep seismic profiles have been ${ }_{13}$ exploited to produce maps of average crustal velocities and thickness across the region. 14 The crustal thickness varies from $29 \mathrm{~km}$ at the southern tip of India to $88 \mathrm{~km}$ under the 15 Himalayan collision zone, and the patterns of variation show significant deviations from ${ }_{16}$ the predictions of global models. The average crustal shear velocity (Vs) is low in the 17 Himalaya-Tibet collision zone compared to Indian shield. Major crustal features are: (a) 18 the Eastern Dharwar Craton has a thinner and simpler crustal structure crust than the 19 Western Dharwar Craton, (b) Himalayan crustal thickness picks clearly follow a trend 20 with elevation, (c) The rift zones of the Godavari graben and Narmada-Son lineament ${ }_{21}$ show deeper depths of crust than their surroundings, and (d) most of the Indian cratonic 22 fragments, Bundelkhand, Bhandara and Singhbhum, show thick crust in comparison to 23 the Eastern Dharwar Craton. Heat flow and crustal thickness estimates do not show any 24 positive correlations for India.

Estimates of the thickness of the lithosphere show large inconsistencies among various 26 techniques not only in terms of thickness but also in the nature of the transition to the ${ }_{27}$ asthenosphere (gradual or sharp). The lithosphere beneath India show signs of attrition 28 and preservation in different regions, with a highly heterogeneous nature, and does not 29 appear to have been thinned on broader scale during India's rapid motion north towards 
30 Asia. The mantle transition zone beneath India is predominantly normal with some

31 clear variations in the Himalayan region (early arrivals) and Southwest Deccan Volcanic

32 Province and Southern Granulite Terrain (delayed arrivals). No clear patterns on in-

33 fluence on the mantle transition zone discontinuities can be associated with lithospheric

34 thickness. Over 1000 anisotropic splitting parameters from SKS/SKKS phases and 231

35 using direct $\mathrm{S}$ waves are available from various studies. The shear-wave splitting results

36 clearly show the dominance of absolute-plate-motion related strain of a highly anisotropic

${ }_{37}$ Indian lithospheric mantle with delay times between the split S phases close to $1 \mathrm{~s}$. There

38 are still many parts of India where there is, at best, limited information on the charac-

39 ter of the crust and the mantle beneath. It is to be hoped that further installations of

40 permanent and temporary stations will fill these gaps and improve understanding of the

41 geodynamic environment of the Indian subcontinent.

42 Keywords: Moho; Mantle Transition Zone; Lithosphere-Asthenosphere Boundary;

43 Deep Seismic Sounding; Receiver Functions; Indian Shield

\footnotetext{
*Corresponding Author

Email address: arun@gg.iitkgp.ernet.in (Arun Singh)

Preprint submitted to Tectonophysics
} 
44 Contents

45 1 Introduction 4

$\begin{array}{lllr}46 & 2 & \text { Tectonic setting } & 6\end{array}$

$47 \quad 3$ Crust and crust-mantle boundary $\quad 8$

$48 \quad 3.1$ Average crustal velocities . . . . . . . . . . . . . . . . . 9

$49 \quad 3.2$ Moho depth . . . . . . . . . . . . . . . . . . . . . 12

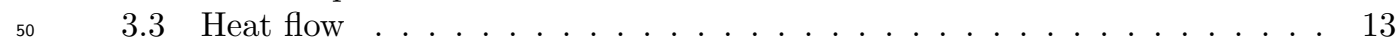

513.4 Comparison of Receiver functions and DSS . . . . . . . . . . . 14

524 Lithospheric mantle $\quad 15$

$53 \quad 4.1$ Seismic Wavespeed variations . . . . . . . . . . . . . . . 16

$54 \quad 4.2$ Lithospheric discontinuities and transitions f . . . . . . . . . . . . 17

$55 \quad 4.3$ Effects of lithospheric thickness variation . . . . . . . . . . . . . . . 21

$56 \quad 4.4$ Seismic anisotropy . . . . . . . . . . . . . . . . . 22

$57 \quad 5 \quad$ The 410 and 660 Mantle Discontinuities 24

$5.1410 \mathrm{~km}$ discontinuity . . . . . . . . . . . . . . . . . . . . . . . . . . . . . .

$5.2660 \mathrm{~km}$ discontinuity . . . . . . . . . . . . . . . . . . . . . . . . . . . . . . . . . 6

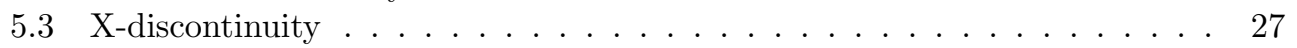

$\begin{array}{lll}6 & \text { Summary } & 27\end{array}$

$\begin{array}{lll}62 & \text { Acknowledgements } & 30\end{array}$

63 References $\quad 30$ 


\section{Introduction}

The Indian subcontinent is formed of a mosaic of various Precambrian tectonic provinces, with stable shields in peninsular India to actively deforming collision belts in the Himalaya, and has experienced extensive volcanism and rifting. India lies on a fast moving plate and has covered a large distance since its separation from the other components of Gondwana (ca $130 \mathrm{Ma}$ ). The influence of the fast drift on the stability of cratons, and removal of lithospheric roots are key issues which are much debated (Kumar et al., 2007), but as yet are not fully understood.

In the century since the detection of the Mohorovičić discontinuity (Mohorovičić, 1910) from earthquake observations, both controlled source and passive seismic studies have made impressive advances in understanding the nature of the crust and uppermost mantle (Prodehl et al., 2013). Multiple facets of seismic wave propagation can be brought to bear on the structure of the Earth's interior, and help to resolve the key issues related to evolution and nature of the continental crust and upper mantle. To date there have been only limited attempts to provide a full picture of the Indian crust and upper mantle. There have been reviews of heat flow (Roy and Rao, 2000) and deep seismic sounding studies (Kaila and Krishna, 1992; Reddy and Rao, 2013). However, the full range of available information on the crust and upper mantle available from passive source studies have not previously been exploited.

The foundation stones of seismology in India were laid by the pioneering works of Dr. T. Oldham and Dr. R. D. Oldham, the father-son duo. The great Shillong earthquake of 12 th June, 1897 is well documented and reported in the works of R. D. Oldham (Oldham, 1899). This deadly Shillong earthquake achieved the maximum intensity XII on MM scale (Richter, 1958), and provided the impetus for a series of initiatives to install seismographs in India to monitor earthquakes. The first few installations were made of Milne's self registering seismographs in Alipore(Calcutta, now Kolkata), Colaba (Bombay, now Mumbai) and Madras(now Chennai) (Tandon, 1992). An Omori-Ewing seismograph was installed in Simla as a response to the great Kangra earthquake of 
5th April, 1905. In the years from 1929 to 1930, the country was equipped with a few more Milne-Shaw seismographs, initially installed at Colaba observatory Mumbai, then Bombay) and later at few more places in Agra, Calcutta, Hyderabad and Kodaikanal. In the early 1960's five World Wide Standard Seismograph network (WWSSN) stations were installed at various places across the country following the recommendations of Berkner (1959). After the devastating Latur earthquake of September 30th, 1993 the Indian Meteorological Department upgraded ten of its observatories to the standard of Global Seismograph Network, and later complemented this network with 14 more broadband stations during 1999-2000. At present the Indian Meteorological Department runs nearly 80 seismic stations in the national network, supplemented by various temporary networks operated by other organizations. Temporary and permanent networks in different parts of India have been operated by the National Geophysical Research Institute, Indian Institute of Technology Bombay, Wadia Institute of Himalayan Geology, Tezpur University and the Institute of Seismological Research. The National Geophysical Research Institute has established more than 200 broadband seismic stations at various points of time, and so plays a major role in passive source seismology in India.

Deep seismic probing of Indian crust, started in 1972 with refraction/wide-angle reflection work, but subsequently was dominated from the early nineties by deep seismic reflection. A good deal has been achieved (Kaila and Krishna, 1992), with more than $10,000 \mathrm{~km}$ of profiles carried out in various experiments using controlled sources. A major supplementary source of information on Indian structure comes from the use of seismic receiver functions exploiting the recordings of distant earthquakes. Receiver functions provide a tool to map the Earths response beneath a single three-component seismic station, and extract information on the seismic discontinuities at depth from the conversions and reverberations associated with the main seismic phases. The first receiver functions for the Indian region used data from the Hyderabad station (HYB) in India, using P-to-s converted waves (Gaur and Priestley, 1997). Since then the role of receiver functions in determining crust and upper mantle discontinuities (Moho, lithosphere-asthenosphere 
boundary, mantle transition zone discontinuities 410 and 660) has been routine practice.

Further information comes from seismic anisotropic studies using SKS/SKKS phases and heat flow that provide links to help understand both geodynamics and structure. The present work presents as a complete picture of the Indian crust and upper mantle as possible, compiled from various sources with emphasis on passive source seismic datasets. We synthesize results from seismic studies, heat flow and seismic anisotropy to develop a comprehensive map of the properties of the crust and upper mantle beneath the Indian subcontinent, with links into the Himalaya and Tibet to provide a wider perspective and understanding of the whole region.

\section{Tectonic setting}

The major tectonic units of peninsular India comprise Precambrian terranes (Figure 1). A vast region in between the peninsula and the actively deforming regions of Himalaya and Tibet is covered by quaternary sediments. These sediments, mainly of Himalayan origin, form the Indo-Gangetic plains with very thick sedimentary deposits ( $>8 \mathrm{~km})$.

The western central portion of India is overlain by flood basalts known as the Deccan Traps or the Deccan Volcanic Province (DVP). The Indian plate has crossed over various hotspots (Rèunion, Krozet, Kergulean and Marion) in its rapid transit to the north. The passage over the Rèunion hot spot (Chenet et al., 2007) has led to a major volcanic event, which resulted in creation of the Deccan Traps. The flood basalts are of considerable thickness $(>1.5 \mathrm{~km})$ and cover a region of more than $500,000 \mathrm{~km}^{2}$. Recent results from Deep Scientific Drilling in the Koyna region provide direct estimates of a $931 \mathrm{~m}$ thick basaltic layer followed by a paleoregolith of thickness $4 \mathrm{~m}$ (Rao et al., 2013). The Cambay Rift (CBR) divides the Deccan Traps into two distinct units, one in the northwest and the other in the southwest. The Cambay Rift is filled with tertiary sediments, and is interpreted as a failed rift formed due to extensional tectonics.

The other major rift systems are the Godavari Graben (GG) and the Mahanadi Rift (MHR), which are passive in nature but which have left clear imprints on the surface. 
The approximately east-west Narmada-Son Lineament (NSL), which originated in the Archean, is another prominent feature that divides various tectonic zones to the north and south (Meert et al., 2010). The southernmost part of the Indian peninsula is termed the Southern Granulite Terrain (SGT). This consists of high-grade granulites of late Archean to Neoproterozoic age, traversed by various shear zones (Meert et al., 2010).

The Indian landmass is host to a number of Proterozoic basins with significant sedimentation namely the Vindhyan Basin (VNB), Chattishgarh Basin (CTB), Godavari Graben and Cuddapah Basin (CB) related to various collisional events. The Godavari Graben and Cuddapah Basin, are of considerate importance as they throw light on the collision events related to Antarctica and India since the Proterozoic. The southern margin of the Singhbhum craton and the eastern margin of the Bastar Craton (BC) are girdled by the Eastern Ghats Belt (EGT), a Proterozoic granulite terrane widely considered to have formed during orogenic collisions between eastern India and east Antarctica (Dobmeier and Raith, 2003).

The Indian craton is formed of a mozaic of a few smaller cratons (Taylor et al., 1984). These stable parts of the Indian shield include the Dharwar Craton, Bastar Craton, Singhbhum Craton (SC), Bundelkhand Craton (BUC) and Aravalli Craton (part of the Delhi-Aravalli Fold Belt, DAFB). These cratons are basically low to high-grade crystalline rocks formed by intense deformation and metamorphism in the Precambrian. The Dharwar Craton is separated into the Eastern Dharwar Craton (EDC) and Western Dharwar Craton (WDC) by the north-south trending Closepet Granite (CG) (Figure 1).

Northeast India under the influence of the Himalayan collision is a region of complexity, at one side are the Indo-Burmese Ranges and at the other are the collisional belts of the Himalaya, in between are the Shillong Plateau (SP) and the Mikir Hills (MKH). The Himalaya-Tibet collision zone formed due to collision of Indian and Eurasian plates, and is comprised of various blocks which are separated by suture zones (Indus-Tsangpo Suture Zone, ITSZ; Bangong-Nujiang Suture Zone, BNSZ). South of Indus-Tsangpo Suture Zone, lies the Himalaya, which is bounded by various north dipping Cenozoic faults 
systems like Main Boundary Thrust (MBT) and Main Central Thrust (MCT). The region between Indus-Tsangpo Suture Zone and Bangong-Nujiang Suture Zone, is known as the Lhasha terrane, adjacent to the Quiangtang terrane (Yin and Harrison, 2000), while the Quiantang terrane is situated between the Bangong-Nujiang Suture Zone and the Jinsha Suture Zone (JSZ) (Figure 1).

\section{Crust and crust-mantle boundary}

The seismological definition of the Moho is linked to the rapid rise in seismic wavespeeds between the crust and the mantle (Prodehl et al., 2013). The transition from crust to mantle is not always sharp, and there can be differences in the interpretation of the seismological and petrological definitions of the base of the crust (O'Reilly and Griffin, 2013). However, seismological results provide the most comprehensive coverage of the nature of the crust and its boundary with the mantle including constraints on the variation of physical properties, such as density and seismic wavespeed, with depth.

Many of the results for the Indian subcontinent come from crustal models extracted from receiver functions (Langston, 1979) beneath three-component seismic stations, from the Indian shield to the actively deforming regions of Himalaya and Tibet. Before we discuss the crustal models, we provide a brief discussion of receiver functions as a passive method, since this approach in recent decades has provided most of the information on the major discontinuities beneath a seismic station. The idea of exploiting teleseismic P waveforms for crustal information starts with Phinney (1964) who exploited the Fourier spectral amplitude ratios of these waves recorded at various World-Wide Standard Seismograph Network (WWSSN) stations. Receiver functions can be computed both in the frequency (Phinney, 1964; Kurita, 1973) and time domain (Jordan and Frazer, 1975; Burdick and Langston, 1977; Langston, 1979), with various advantages and limitations. Much of the work has followed (Langston, 1979), and used frequency domain deconvolution procedure, where the numerically unstable spectral division is taken into account by applying water level (Clayton and Wiggins, 1976). Later a time domain inversion 
technique was developed by Owens et al. (1984) and successfully implemented by various workers with certain modifications to obtain the one-dimensional velocity structure (Owens and Zandt, 1985; Owens, 1987; Kind et al., 1995). However, the issues of nonuniqueness and non-linearity in the inversion of receiver functions were demonstrated by (Ammon et al., 1990), with complex trade-offs between velocities above interfaces and the depth of apparent conversion. The methods have been developed significantly in recent decades. The weak conversions in individual receiver functions can be enhanced by applying moveout corrections and stacking receiver functions at a single station (Vinnik, 1977; Kind and Vinnik, 1988). More complex structure can be considered by inverting waveforms for layer dip (Zhang and Langston, 1995), or even to recover both anisotropic and dipping effects (Levin and Park, 1997; Frederiksen and Bostock, 2000). However, these more complex schemes increase the non-uniqueness in the inversion of the receiver functions.

The first receiver functions were produced for India using data from Hyderabad station (HYB) located in Eastern Dharwar Craton (Gaur and Priestley, 1997), the only station in the International Federation of Digital Seismograph Networks (FDSN) operating in India since 1989. Thereafter the exploitation of receiver functions to extract crustal discontinuities and Poisson's ratio has become routine with every new installation of broadband seismic station in India. Up until April 2014 data from 442 seismic stations have been used to obtain estimates of crustal thickness and Poisson's ratio for different geological provinces of the Indian sub-continent. Most of these profiles and seismic stations are focused on understanding the geometry of crustal discontinuities beneath the Indian shield (Gaur and Priestley, 1997; Saul et al., 2000; Kumar et al., 2001; Sarkar et al., 2003; Rai et al., 2003, 2005; Gupta et al., 2003; Mohan and Kumar, 2004; Tiwari et al., 2006; Jagadeesh and Rai, 2008; Julià et al., 2009; Kayal et al., 2011; Kumar et al., 2012; Borah et al., 2014a) or north east India (Kumar et al., 2004; Ramesh et al., 2005; Mitra et al., 2005; Hazarika et al., 2012). Efforts are now being made by various workers in the Himalayan region along different seismic profiles in order to understand 
$252 \sim 3.64 \mathrm{~km} \mathrm{~s}^{-1}$. Out of 323 seismic stations in the Himalaya and Tibet, 200 seismic stations

253 have velocities $\leq 3.6 \mathrm{~km} \mathrm{~s}^{-1}$, and 86 even lower than $3.5 \mathrm{~km} \mathrm{~s}^{-1}$. Although the stations are

254 not uniformly distributed, the results are significant and clearly indicate a low velocity

the Moho geometry of the Indian plate beneath the Himalaya (Rai et al., 2006; Caldwell et al., 2013; Singh et al., 2010; Acton et al., 2011; Hazarika et al., 2013a).

In this review we attempt to summarize the full set of results based on thickness and average velocities of the crust for the Indian subcontinent, exploiting passive seismic studies and Deep Seismic Sounding (DSS), and links to other information such as Heat flow. We include crustal information for Tibet from the compilation of Li et al. (2014) to provide a more complete picture of the collisional structures to the north.

\subsection{Average crustal velocities}

Maps of average crustal velocity and Poisson's ratio from passive seismic studies are presented in Figure 2. The average velocity models employed are the end results of: (a) 1-D inversion schemes mostly on receiver function stacks for a particular seismic station (b) use of the approach of Zhu and Kanamori (2000) for average Poisson's ratio and Moho depth, and (c) a few instances where data has has been inverted for velocities incorporating both dipping and anisotropic effects (Sherrington et al., 2004; Singh et al., 2010). In most cases the emphasis is on Vs rather than Vp. Frequently Vp is fixed from previous results of deep seismic sounding, standard velocity models, or seismic tomography.

There are significant variations in the average crustal velocities and Poisson's ratio across the Indian subcontinent, with some very clear trends (Figure 3 ). The regions of the Himalaya and Tibet show significantly lower $\operatorname{Vs}\left(\sim 3.57 \mathrm{~km} \mathrm{~s}^{-1}\right)$ than in the Indian shield (3.7-3.75 $\mathrm{km} \mathrm{s}^{-1}$ ) (Figure 2). The Himalayan foredeep seismic stations, and stations the Indo-Gangetic alluvium plains have an intermediate range with an average Vs of crust in the collision zone. The observed low velocities are characteristics of orogens (Christensen and Mooney, 1995), and most likely represent a felsic-to-intermediate nature 
for the crust. Such low shear wavespeeds are also reported in earlier compilations for Tibet and surrounding regions (Stolk et al., 2013; Chen et al., 2010).

In northeast India, the seismic stations located over the Shillong Plateau (centred around $92^{\circ}$ longitude and $25.5^{\circ}$ latitude) can be distinguished from the neighbouring regions by relatively high shear velocities $>3.7 \mathrm{~km} \mathrm{~s}^{-1}$. The shield-like character of Shillong Plateau has been reported by various workers (Kumar et al., 2004; Mitra et al., 2005). In the Indian shield itself, of the 120 seismic stations which fall in the regions of Dharwar Craton, Deccan Volcanic Province, Bundelkhand Craton, Singhbhum Craton, Bastar Craton and Southern Granulite Terrain, only 25 show velocities less than 3.6 $\mathrm{km} \mathrm{s}^{-1}$. The observed high velocities in the regions of Indian shield in comparison to the Himalaya is clear and obvious. Seismic stations on the west coast of India have somewhat lower crust shear wavespeed than in the shield (Figure 2b).

A more subtle difference appears between the Eastern Dharwar Craton(Vs $\sim 3.71$ $\mathrm{km} \mathrm{s}^{-1}$ ) and the Western Dharwar Craton(Vs $\left.\sim 3.73 \mathrm{~km} \mathrm{~s}^{-1}\right)$. The difference is almost negligible given the uncertainities (Figure S1). A higher velocity crust beneath the Western Dharwar Craton and a lower velocity crust beneath Eastern Dharwar Craton is reported in a number of studies (Sarkar et al., 2003; Gupta et al., 2003; Borah et al., 2014a), however such a difference is restricted to the geographic patterns in the core central portions (Figure 2b) of Eastern and Western Dharwar Craton.

The Poisson's ratio is around normal (0.24-0.27) for significant parts of the Dharwar craton, Southern Granulite Terrain and basins like Cuddapah (Figure 2a). The somewhat lower Poisson's ratio for the Western Dharwar Craton (Sarkar et al., 2003; Gupta et al., 2003) than the Eastern Dharwar Craton, may possibly be due to a more felsic upper crust with Poisson's ratio $<0.25$, while the lower portion of crust may have mafic velocities with a correspondingly higher Poisson's ratio. These inferences by Sarkar et al. (2003), are further validated by Kiselev et al. (2008) who jointly inverted P-to-s and S-to-p receiver functions.

The crustal composition for the Deccan Volcanic Province inferred from available 
Poissons ratio information $(\sim 0.26)$, does not reflect its actual composition due to an uneven distribution of sampling. Most of the stations are close to the Western Ghats, or at the eastern most boundaries of the Deccan Volcanic Province. The DVP is classified as more felsic-to-intermediate in nature by Kumar et al. (2001). However, Kiselev et al. (2008) using P-to-s and S-to-p receiver functions, found the Deccan Volcanic Province composition to lie between the Eastern and Western Dharwar Cratons, with a layer of mafic velocities. A high Poisson's ratio is observed across the Narmada-Son lineament $(\sim 0.28)$ and the Western Ghats. The paleo-rift Narmada-Son Lineament is traced by two N-S profiles in different experiments (Rai et al., 2005; Jagadeesh and Rai, 2008) The crust beneath the Narmada-Son Lineament found to be more mafic in nature with high $\mathrm{Vp} / \mathrm{Vs}$ ratios (1.84 to 1.91, Table S1) than its surroundings and is suggestive of a high-density mafic mass at depth that compensates the crustal root, also supported by the small topographic variation $(\sim 200 \mathrm{~m})$ across the lineament (Rai et al., 2005).

In the Himalaya-Tibet collision zone, the average Poisson's ratio is 0.26 , with strong variations over range from 0.16 to 0.32 . A total of 107 stations show Poisson's ratio $<0.25$, while 189 have a ratio $\geq 0.25$. The skew is clearly seen on the sides of the zone of high Poisson's ratio in Figure 2a. Examing the distribution based on nodal points (sampling of $0.25^{\circ} \times 0.25^{\circ}$ ), we find $\sim 80 \%$ of the region has higher Poisson's ratio, with most centred around 0.26 . With a sampling of $1^{\circ} \times 1^{\circ}$ the region with Poisson's ratio $\geq 0.25$ is even greator $(\sim 92 \%)$. These results provides a better understanding of the region, in view of the uneven station distribution (Figure 2a). The high Poisson's ratio beneath most of the Tibet plateau suggests the presence of partial melts/fluids, as interpreted in various studies (Owens and Zandt, 1997; Li et al., 2006, 2009).

Figure 3 illustrates summary properties of the crust for specific geological regions: (a) Himalaya and Tibet, (b) the cratonic regions and Southern Granulite Terrain (c) the rift systems of the Narmada-son lineament and Godvari Graben and (d) the Deccan Volcanic Province. The strong constrasts between the orogenic belts of the Himalaya and Tibet and peninsula India is very evident in Figure 3. We can also recognise the area masked 

$3324)$.

333

334

by the Deccan Volcanic Province as having strong cratonic affinities.

\subsection{Moho depth}

Variations in the depth to the crust are large across the Indian region, ranging from a minimum of $29 \mathrm{~km}$ to a maximum of $88 \mathrm{~km}$ in depth. The shallowest crust is for stations close to the coastal plains of the peninsular India, and the deepest under the highest mountain ranges of Himalaya. The crustal thickness variation presented in Figure 4 represents results from 615 seismic stations from various studies (Figure 4). The regions of southern Indian shield and Himalaya-Tibet collision zone are well covered, while gaps exist in central India, mainly in the Indo-Gangetic belts and Bastar and Singbhum Cratons.

In the Dharwar Craton a clear cut difference is observed between the different components. The Eastern Dharwar Craton exhibits a thinner crust, $\sim 35 \mathrm{~km}$, while in the Western Dharwar Craton average crustal thickness estimates are $\sim 45 \mathrm{~km}$. An interesting and unusual observation is a very thick crust, in the central portion of Western Dharwar Craton (Gupta et al., 2003). One of the reasons suggested, is that the thickened crust beneath a mid-Archaean (3.4 Ga) greenstone belt has not been subjected to any major deformation, and may preserve an ancient crust of around $60 \mathrm{~km}$ thickness (Gupta et al., 2003). The same seismic station (MTP, Table S1) has been reported with a crustal thickness of $45 \mathrm{~km}$ (Julià et al., 2009), which is preferred for creating the map (Figure

The crust of the Eastern Dharwar Craton with a sharper Moho is thinner and more transparent than the Western Dhawar Craton, with an absence of any intracrustal layer (Sarkar et al., 2003). The absence of any seismically distinct mafic cumulates overlying the Moho and an intermediate to felsic nature of Eastern Dharwar crust, rather than complex nature of Western Dharwar Craton crust was reported by almost all workers. Receiver functions for the Western Dharwar Craton stations are more complex and show a gradational transition from crust to mantle (Gupta et al., 2003; Sarkar et al., 2003). 
The Southern Granulite Terrain, has a relatively thick crust $(\sim 42 \mathrm{~km})$, close to that for the Western Dharwar Craton.

An interesting observation is that the crustal thickness increases as we advance in the Himalayan collision zone, stations in the Himalayan regions have crustal thickness in the range $40-50 \mathrm{~km}$, while the central Tibet exhibits a highly thickened crust (around $75 \mathrm{~km})$. A few regions such as the Tarim Basin and the Qaidam Basin clearly stand out from the Tibetan plateau with a thinner crust (Figure 4).

\subsection{Heat flow}

Ongoing deformation and the presence of large scale inhomogeneity across regions are well reflected in the geothermal heat distribution for India and its environs. Previously, several studies have established a positive correlation between heat flow and crustal thickness (e.g., Bodri and Bodri, 1985), while many others have shown no obvious relationship exists between these two parameters, (e.g., Mareschal and Jaupart, 2013). Using heat flow results, from the global data base of the International Heat Flow Commission, with additional new measurements (Nagaraju et al., 2012), we examine the correlation with crustal thickness for India and Tibet.

The regions with heat-flow values lower than the average value, $60 \mathrm{mWm}^{-2}$, are regarded as low-heat-flow and those with heat-flow above the average above are classified as high-heat-flow (Figure 6). Continental heat flux exhibits lower value in stable regions compared to the active provinces. Moreover there are some discrepancies observed in correlation of surface heat flux with crustal thickness while comparing between tectonically active region having high heat flux $\left(>65 \mathrm{mWm}^{-2}\right)$ with anomalously thin $(<30$ $\mathrm{km}$ ) or thick $(>55 \mathrm{~km})$ crust and stable region having relatively low surface heat flux $\left(<65 \mathrm{mWm}^{-2}\right)$ with little variations in crustal thickness (Mareschal and Jaupart, 2013). It is also apparent in our case where a distinct correlation exists between high-heat-flow and thick crust in the Himalayan collision zone as well as in Tibet. Certain parts of peninsular India the Cambay basin, the Godavari Graben and some parts of the Singhbhum craton show higher heat flow, which does not link with their crustal thickness. The 
thinner crust of the Qaidam Basin correlates well with a low heat flow value. Thick crust mostly relates to high heat flow values, but no correlation has been found for normal to thin crust. This may be due to the diversity in crustal compositions as well as the evolution of the heat production in the crust (Mareschal and Jaupart, 2013).

\subsection{Comparison of Receiver functions and DSS}

We can supplement the passive seismic results in some areas with work using controlled sources. Deep Seismic Sounding studies provide information through the full thickness of the crust and are available for profiles extending over more than ten thousand kilometres across the Indian landmass. The locations of the various controlled source profiles are shown in Figure 7.

The crustal thickness picks been made across various Deep Seismic Sounding profiles covering Indian shield and parts of Himalaya. The picks are made at regular intervals from modelling results for the profiles 1-29 (Figure 7), with due allowance for the drastic changes in the depth of the Moho. For Tibet, the crustal thickness are directly taken from Deep Seismic Sounding and Deep Seismic Reflection profiles as provided in Xiaosong et al. (2009). The station elevation is added to the specific profiles where the Moho estimates are provided with respect to mean sea level. We then employ these crustal thickness values in a similar way to Figure 4 to display the available thickness results from the deep seismic sounding. The map of depth to crust (Figure 8) has sparse coverage, but strong contrasts are evident. The thickened Tibetan crust, as compared to Indian shield and intermediate depths in Tarim and Qaidam basins comes out clearly. Although the controlled source results are somewhat limited, they provide very useful information to fill in some of the gaps in the coverage of the crustal thickness from receiver functions.

We examine the variations and similarities in the results from Deep Seismic Sounding and receiver functions. The overall pattern is of a good linear correlation, but there are just a few outliers, notably in the Himalayan region where the differences reach $20 \mathrm{~km}$ (Figure 9). These differences are likely to be due to varying influences from strong velocity gradients in the different styles of analysis, as receiver functions are more sensitive to 
discrete velocity jumps while refraction are to velocity gradients (Kennett and Salmon, 2012).

The good general compatibility between the results from passive and controlled source seismic studies enables us to combine the two data sets and so produce a more complete map of the depth to crust across the Indian region (Figure 10). The combined map using data points from Deep Seismic Sounding and receiver functions (Figure 10), agrees well in the areas already covered by passive seismic studies (Figure 4), but extends the coverage into a number of important regions (Cambay Rift, Narmada-Son Lineament, Mahanadi Rift, Himalaya and parts of Deccan Volcanic Province). The pattern of variation of the depth to Moho across the Indian subcontinent is well defined, but shows substantial differences from available global models such as CRUST1.0 (Laske et al., 2013), with differences as large as $20 \mathrm{~km}$ in Tibet and along the east coast of peninsular India (Figure $11)$.

\section{Lithospheric mantle}

There are two major tools to investigate the mantle component of the lithosphere. The exploitation of the fundamental and higher modes of surface waves in tomography can determine the broad scale patterns of seismic wavespeed variation in 3-D (Priestley and Tilmann, 2009). The surface waves provide dominantly horizontal sampling, with depth information through the character of the different modes. Horizontal resolution is not better than $250 \mathrm{~km}$ with about $40 \mathrm{~km}$ resolution in depth. This is sufficient to provide indications of the base of the lithosphere, but no details. Alternatively body wave tomography and long-duration receiver functions can provide constraints with near vertical sampling, since they exploit distant earthquakes (Rawlinson et al., 2010). For incident $\mathrm{P}$ waves the conversions associated with discontinuities in the lithospheric mantle overlap with reverberations in the crust, and so can be difficult to disentangle. On the other hand the $\mathrm{p}$ converted waves from incident $\mathrm{S}$ waves arrive before the main phase and are unaffected by such reverberations (Kumar et al., 2007). However, the available 
423

424 as apparent discontinuities.

\subsection{Seismic Wavespeed variations}

Results from surface wave tomography are very limited for peninsular India, because only the HYB station and some stations in Sri Lanka and the Maldive islands are available for open access. The situation is much improved in the eastern Himalayan region because of the many temporary deployments of seismometers in different parts of Tibet and adjacent regions of China, but coverage diminishes to the west. Figure 2 of Pandey et al. (2014) illustrates the very strong contrast in available path densities in the two regions when using regional stations. Global studies (e.g. Debayle et al., 2005; Schaeffer and Lebedev, 2013) can provide some improvement in coverage by exploiting longer paths traversing India and its environs, but resolution remains limited.

The surface wave tomographic results suggest a slight contrast between the southern tip of India and the the zones to the north. The detailed study of Rayleigh wave dispersion by Borah et al. (2014b) is focussed on the Dharwar craton, but extends somewhat into the Southern Granulite Terrane. The detailed 3-D shear wavespeed model suggests that the contrast in the lithosphere occurs somewhat south of the surface transition.

A contrast in the mantle lithosphere at the southern tip of India was presented in the P wavespeed model of Kennett and Widiyantoro (1999) derived from regional body-wave tomography, though the available resolution was poor. The recent body-wave tomography study by Singh et al. (2014) was able to exploit a larger, and better distributed, suite of stations and thereby achieve nearly uniform resolution at $2 \times 2^{\circ}$ of both $\mathrm{P}$ and $\mathrm{S}$ wavespeeds across peninsular India . The results of Singh et al. (2014) indicate distinct contrasts at about the $1 \%$ level in wavespeed between the southern tip and the cratonic zone to the north in the top $200 \mathrm{~km}$ of the mantle.

Because most sampling in body-wave tomography is near vertical, except where regional earthquakes can be exploited, vertical smearing of structure is very common. Nevertheless, some indications can be extracted on the relative thickness of different 
lithospheric blocks identified by lateral variations in seismic wavespeed. The body-wave tomographic results of Singh et al. (2014) indicate varying thickness of lithospheric roots beneath India and Tibet, most likely arising from various geodynamic events that affect the preservation and attrition of the lithosphere at various epochs.

\subsection{Lithospheric discontinuities and transitions}

The lithosphere is a thermal boundary layer which is mechanically strong zone due to colder temperatures near the Earth's surface and is underlain by a weaker zone the asthenosphere. The transition between the two elements is an important component of the Earth system since it accommodates differential motion between tectonic plates and underlying mantle. But, depending on what class of geophysical and geochemical information are examined there are many different ways of assessing the base of the lithosphere. A succinct summary is provided in Chapter 1 of Artemieva (2011).Geochemical and isotopic evidence suggest that the lithospheric mantle is largely depleted in character due to the extraction of basaltic components. The lithosphereic mantle beneath the continents shows a trend of increasing metasomatic refertilization for younger ages, a phenomenon attributed to episodes of melt and fluid infiltration from the underlying asthenosphere (O'Reilly and Griffin, 2010). The asthenospheric mantle is regarded as much more fertile due to the recycling of crustal components during subduction. Thus, in addition to being a mechanical-thermal boundary, the lithosphere-asthenosphere transition also marks a major break in the chemical composition of the subcontinental mantle (O’Reilly and Griffin, 2010).

In some places the lithosphere-asthenosphere boundary (LAB) is sharp enough to be viewed as a discontinuity, but in many places beneath cratonic lithosphere the transition is gradual (see e.g., Yoshizawa, 2014). Other potential discontinuities in cratonic lithophere are the Hales discontinuity (HD) and the mid-lithospheric discontinuity (MLD). The Hales discontinuity at 80-100 km depth has been associated with either depth localized anisotropy (Bostock, 1998) or phase change from spinel to garnet peridotite (Hales, 1969) and visible by wide-angle seismic reflection with a positive velocity jump (Ayarza 
et al., 2010). The MLD is reported as having a decrease in seismic wavespeed within continental interiors, and has been attributed to alteration by melt or metasomatism (Ford et al., 2010) or a change in anisotropy (Yuan and Romanowicz, 2010). We attempt to analyse the results obtained from various studies in the Indian region that see HD, MLD and the LAB reported at almost similar depths.

There is a wide range of estimates for the thickness of the lithosphere using different techniques (Figure 12). Studies using S-p receiver functions (Kumar et al., 2007; Devi et al., 2011; Kumar et al., 2013b) cover much of India and give estimates in the range 70-140 km. At HYB station (Rychert and Shearer, 2009) using P-to-s receiver functions estimate $\sim 60 \mathrm{~km}$. From surface wave dispersion estimates range from 80-155 km (Mitra et al., 2006; Bhattacharya et al., 2009). McKenzie and Priestley (2008) have used surface wave tomography with empirical relations to convert shear wave velocity to depth, and their results indicate variations from $\sim 100-280 \mathrm{~km}$ from south to north (Figure 12b).

Joint inversion of P-to-s and S-to-p receiver functions (Kiselev et al. (2008), Dharwar craton; Oreshin et al. (2008), western Himalaya and Ladakh; Oreshin et al. (2011), Indian shield, western Himalaya and Ladakh) have revealed low shear velocities $4.4-4.5 \mathrm{~km} \mathrm{~s}^{-1}$ beneath the Indian shield, much lower than found elsewhere beneath Precambrian shields. The authors suggest metasomatic alteration of the high velocity keel by some recent tectonic event. Using P-to-s and S-to-p receiver functions from four seismic stations beneath the Dharwar craton Ramesh et al. (2010) argued in favour of a thick lithosphere on the lines of the idea of a tectosphere (Jordan, 1988). This interpretation is based on presence of two westerly dipping interfaces at depths of 150 and $200 \mathrm{~km}$. However, they refrain to reporting the low-velocity-zone observed at around $10 \mathrm{~s}$ as a possible LAB. The high shear velocities of $4.7 \mathrm{~km} \mathrm{~s}^{-1}$ in the depth range $100-150 \mathrm{~km}$ beneath the western Himalaya is suggested to be a recovery of a shield-like structure (Oreshin et al., 2011).

Not only is there considerable variation in the estimates of depth to the base of the lithosphere from different methods, but there are also very different reports on the sharpness of the transition and the velocity change across the LAB, particularly in the 
old cratonic regions. Kumar et al. (2007, 2013b) describe the LAB as a sharp boundary, while other authors do not report the LAB as a rapid transition (Mitra et al., 2006; Kiselev et al., 2008; Oreshin et al., 2008, 2011).

Beneath the oceanic lithosphere Kawakatsu et al. (2009) has used observations of S-to-p receiver functions at $0.25 \mathrm{~Hz}$ to infer a very sharp change at the LAB, associated with partial melting in lenses in the asthenosphere. This model has been also invoked by Kumar et al. (2013b), as a possible explanation for a sharp continental transition. However, such models including partial melt have limitations, and may not be concordant with all aspects of the geodynamics. For example, Karato (2012) suggests anelastic relaxation caused by elastically accommodated grain boundary sliding can explain large velocity drops at a mid-lithospheric discontinuity (MLD), while there would be less contrast across the LAB. The presence of a MLD (Yuan and Romanowicz, 2010) provides an alternative explanation to the thin lithosphere beneath cratons reported in various studies of P-to-s and S-to-p receiver functions (Kumar et al., 2007; Rychert and Shearer, 2009). Beneath India, Kumar et al. (2013b) argued that their observations of thin lithosphere does represent the LAB, not the MLD; they interpret another reflection at much shallower depths at a few stations as the MLD beneath India.

Discrepancies remain between inferences made using different methods. For example, Mitra et al. (2006) have reported the LAB as a gradational boundary layer beneath Indian shield from Rayleigh wave phase-velocity measurements. However, in another study Kiselev et al. (2008) show that synthetic seismograms using the velocity models of Mitra et al. (2006) do not reflect a layer which can be matched with actual S-p receiver functions. The difficulties arise because the results from analysis of surface waves naturally favour rather smooth variations in depth, since minor fluctuations cannot be resolved. Yet, it is precisely such rapid variations that would give rise to signals that could be interpreted as discontinuities in the analysis of receiver functions.

Hales (1969) reported a seismic discontinuity at a depth of 80-90 km south of Lake Superior from the analysis of seismic refraction profiles. Since then, there has been on-going 
debate on its nature, the cause of its existence, and whether it is a global phenomenon or a just a regional feature. The first report of the Hales discontinuity beneath India was made by Saul et al. (2000) for the station HYB, located in the northeastern part of Dharwar craton, at a depth of $90 \mathrm{~km}$. They were uncertain about the origin of the observed energy on the transverse (SH) component, and attributed it to an anisotropic layer, taking a clue from the results of Bostock (1998). Elsewhere the presence of the H-discontinuity has been proposed from south to north across India, using data from a few stations (Jagadeesh and Rai, 2008). Such an interpretation is supported by velocity models presented by Mitra et al. (2006), who reported an increase in S-velocity from 4.52 to $4.77 \mathrm{~km} \mathrm{~s}^{-1}$ at depths of near $75 \mathrm{~km}$. Positive velocity jumps are also reported for certain stations in the Western Dharwar Craton, Deccan Volcanic Province and for station HYB (Kiselev et al., 2008). In the S velocity profiles for azimuths around $100^{\circ}$ a distinct positive discontinuity was reported in the depth interval of 80 to $100 \mathrm{~km}(80 \mathrm{~km}$ for HYB, $120 \mathrm{~km}$ for Western Dharwar Craton and $100 \mathrm{~km}$ for Deccan Volcanic Province), however this feature is missing for azimuths between $30^{\circ}$ and $50^{\circ}$ (Kiselev et al., 2008). To establish the existence of the Hales discontinuity beneath India is a challenge because of the limited backazimuthal coverage of the data sets available for use in such studies. A point of concern is the reports of $\mathrm{HD}$ and $\mathrm{LAB}$ at almost similar depths beneath India. For one of the most thoroughly studied seismic stations HYB, we have inferences of the LAB at 99-101 km depth from S-p receiver functions (Kumar et al., 2007, 2013b) and $\mathrm{HD}$ at depths of $90 \mathrm{~km}$ from P-to-s receiver functions (Saul et al., 2000). Reconciling such results is not at all easy, and often anisotropy is invoked. Clear analysis of the such lithospheric discontinuities needs joint application of multiple techniques if more reliable results are to be obtained.

Body-wave tomographic results do not provide direct estimates of lithospheric depth, but reveal thick high velocity perturbations observed at depths greater than $200 \mathrm{~km}$ (Singh et al., 2014), while receiver function studies infer strong variations at much shallower depths (60-140 km, Kumar et al., 2013b; Rychert and Shearer, 2009). 
Concepts that have been employed to try to reconcile the results from tomography and receiver functions, are the differences between chemically and thermally defined lithosphere, the presence of mid-lithospheric discontinuities and a depleted fertile lithosphere (O'Reilly and Griffin, 2010). Even within tomographic studies many differences arise depending on the data employed, particularly beneath the Indian shield (Singh et al. 2014; McKenzie and Priestley, 2008).

The Lehmann discontinuity, at depths around $220 \pm 30 \mathrm{~km}$ beneath continents could be associated with the bottom of lithosphere, marking a transition to asthenospheric anisotropy (SH leading SV) related to present day flow (Gung et al., 2003). Such a scenario is present beneath India, where APM related asthenospheric anisotropy, with SH leading SV is reported using direct S and SKS/SKKS phases (Kumar and Singh, 2008; Saikia et al., 2010). Reports of the Lehmann discontinuity beneath India and Tibet are meagre, (Sharma and Ramesh, 2013; Kiselev et al., 2008; Kosarev et al., 2013; Heit et al., 2010; Oreshin et al., 2011; Wittlinger et al., 2004), but suggest a deeper boundary (> $200 \mathrm{~km}$ ) than that commonly inferred from S-to-p receiver functions. Beneath the stable parts of Indian shield, the Lehmann discontinuity may define the lithosphere boundary (Gung et al., 2003), revealed in body wave tomographic images.

The conspicuous and intermittent nature of this discontinuity ( $\mathrm{Gu}$ et al., 2001) and discrepancies to associate Lehmann as a boundary between anisotropic and isotropic medium (Vinnik et al., 2005), remain as ongoing issues.

\subsection{Effects of lithospheric thickness variation}

Various studies have proposed that the exceptionally fast motion of the Indian tectonic plate has been facilitated by the thinning of the Indian lithosphere (Negi et al., 1986; Kumar et al., 2007, 2013b). However body-wave tomographic studies do not suggest strong lithospheric thinning. The issue of the fast drift of the Indian tectonic plate is not that simple, and needs to be understood in terms of effects of various possible candidate mechanisms. Slab pull and ridge push models are considered to be possible mechanisms for the fastest drift of Indian tectonic plate (Copley et al., 2010; Capitanio et al., 2013). 
The role of plumes has been also considered to facilitate the fast drift of Indian tectonic plate. A substantial push force due to the Réunion plume is thought to be responsible for the speed-up and subsequent slowdown of Indian plate (Capitanio et al., 2013), although the issues of the time period of anomalous Indian plate motion and of plume activity along with its impact on acceleration of India remains unsolved (Muller, 2011). The presence of the mantle conveyor belt deduced from mantle density distributions may also have played a role in the breakup and be responsible for the indentation of Indian and Arabian plates (Becker and Faccenna, 2011). The presence of such a conveyor belt may impact on the extent of slab pull and ridge push forces, which then contribute as a secondary driving mechanisms with mantle upwelling and active drag as primary (Becker and Faccenna, 2011).

\subsection{Seismic anisotropy}

The rapid movement of the Indian plate (with velocities reaching up to $20 \mathrm{~cm} / \mathrm{yr}$ ) and its quite variable surface geology makes it unique in comparison to other shield regions. In this context, seismic anisotropy parameters extracted from SKS/SKKS phases allow the investigation of a number of significant geodynamic questions: (a) do the distinct geologic provinces show disparate anisotropic character? (b) does the fast moving plate force deformation in the plate motion direction? or (c) is anisotropy from the past tectonic events frozen in the lithosphere? Although large data sets of seismic anisotropic parameters have been acquired from various Precambrian shields world wide, published measurements from the Indian shield are limited before 2006 (Singh et al., 2006). A few measurements exploiting analogue data, reveal dominance of Absolute Plate Motion related strain (Ramesh et al., 1996). The results from a single seismic station SHIO located over Shillong plateau, show anisotropic directions parallel to the strike of mountain belts (Vinnik et al., 1992). Later on results using HYB and SHIO (Chen and Ozalaybey, 1998) and HYB (Barruol and Hoffmann, 1999) seismic stations are found to be null. Such observations were interpreted in terms of the isotropic nature of Indian lithospheric mantle and onset of seismic anistropy in Tibet north of ITSZ as a marker for northern limit of 
Indian lithosphere (Chen and Ozalaybey, 1998). Now with a flood of seismic high quality data sets in the recent decade it is possible to examine the results from SKS/SKKS and direct-S phases for a complete picture of deformational nature of the Indian plate.

In the period from 2006 to 2013, more than 1000 individual splitting parameters using SKS/SKKS and 231 using direct $\mathrm{S}$ waves have been presented in various studies (Figure 13). The results using SKS/SKKS phases clearly reveal absolute plate motion related strain as the dominant process beneath Indian plate (Kumar and Singh, 2008), with a possibility of modified asthenospheric flow around lithospheric keels. The delay times between the split $\mathrm{S}$ phases are $\sim 1 \mathrm{~s}$, as observed for continental shields globally. The prominent trends observed are (a) NS to NE orientation of the fast axis in southern part of peninsular India, (b) NE orientation in north to central India, (c) NE orientation in Himalayan region east of the Sikkim Himalaya, (d) EW orientation parallel to the mountain belts in northeast India, and e) in the Himalaya and Tibet collision zone the orientation is roughly $\mathrm{EW}$, parallel to major suture zones. Although attempts have been made to characterize the seismic anisotropic character of the stable and actively deforming regions of the Indian plate, a number of issues still remain to be addressed. Since SKS splitting provides an integrated effect of both the crust and the mantle, the crustal contribution to anisotropy needs to be isolated. Approaches that exploit the splitting of Ps phases converted at the Moho to estimate the strength and orientation of the fast axis, in a manner similar to SKS-splitting techniques, need to be adopted. The utility of Ps phases in estimating crustal anisotropy has been demonstrated (McNamara and Owens, 1993), although not widely applied. Studies of crustal anisotropy together with those of the mantle should enable an improved understanding of the nature and extent of coupling between the crust and mantle.

As is well known, SKS/SKKS phases are only sensitive to horizontal anisotropy. Where expected deformation is complex as in the Andaman and Burmese arc regions, analysis of splitting of $\mathrm{S}$ waves from deep earthquakes (to minimize the source side anisotropy) and its modelling in terms of a dipping axis of symmetry can be undertaken. 
However, separating the effects of mid-mantle and receiver side anisotropy is a challenge that must be met when using direct-S waves. The results from Indian shield stations using direct-S waves clearly brings out a close similarity with the SKS/SKKS results (Saikia et al., 2010), as illustrated in Figue 12.

SKS splitting measurements do not directly identify the origin of anisotropy whether anisotropy resides in the lithosphere or in the sub-lithospheric mantle is an open issue. To be able to resolve this debate, there is a need to evolve to strategies that isolate the Ps conversions from deeper anisotropic layers and model them. Since the interference of reverberations from shallow layers and conversions from deeper layers make this task difficult, effective techniques to suppress the multiples need to be developed. Techniques like joint inversion of Ps and SKS phases need to be extended to deal with 2-D situations, which are expected in plate boundary regions. Further, joint inversion of $\mathrm{P}$ and $\mathrm{S}$ receiver functions (that is recently emerging as a powerful tool to map the upper most mantle stratigraphy using Sp conversions) to model the dip and anisotropic effects can be a big step forward. Synthetic tests demonstrate that the Sp conversions are less sensitive to anisotropy, and more importantly separate the converted and multiple phases to naturally lie on either-side of the parent S-wave. Moreover, conversions from the lesser used phases like PP and PKP can be used to fill the backazimuthal gaps resulting from the uneven earthquake source distribution and the short periods of operation of temporary seismic stations. Lastly, data from long running permanent stations hold the key to validate newer methodologies and understand the complex inner workings of the dynamic Earth system.

\section{The 410 and 660 Mantle Discontinuities}

Major discontinuities associated with mineralogical phase transitions are the mantle transition zone at 410 and $660 \mathrm{~km}$. The properties of these discontinuities provide important constraints on the thermal and compositional nature of the mantle. The mineralogical phase transition from olivine $\alpha$-phase to the modified spinel $\beta$-phase at the 410 
$\mathrm{km}$ discontinuity and the ringwoodite $\gamma$-phase to perovskite and magnesiowustite at the $660 \mathrm{~km}$ discontinuity match well with the seismic results. Variations in the depths of these discontinuities in response to vertically oriented mantle temperatures are anti-correlated with positive Clapeyron slope $(\partial P / \partial T)$ at the $410 \mathrm{~km}$ discontinuity and negative Clapeyron slope at the $660 \mathrm{~km}$ discontinuity. The result is a thickened mantle transition zone in presence of trapped cold lithospheric slabs within the transition zone, and early returns from the 410 and 660 in the case the slabs or lithospheric roots lie well above the 410 . The mantle transition zone beneath India is not akin to those observed globally beneath other Precambrian shields. Receiver functions results are frequently used to map the topography of 410 and $660 \mathrm{~km}$ discontinuities (Figure 14). These images for the behaviour at 410 and $660 \mathrm{~km}$ phase arrivals are produced based on the results of individual stations, rather than piercing points, except for those from the work of Singh and Kumar (2009). Thus, they represent a broad picture of the mantle beneath India and Tibet, rather than being suitable to map local variations.

\section{1. $410 \mathrm{~km}$ discontinuity}

The vertical passage time for seismic $\mathrm{P}$ waves to the $410 \mathrm{~km}$ discontinuity is close to that predicted by the ak135 reference model beneath the key cratonic segments of the Indian shield: (Kumar and Mohan, 2005; Ramesh et al., 2005; Rai et al., 2009b; Kiselev et al., 2008; Oreshin et al., 2011; Kosarev et al., 2013; Kumar et al., 2013a). This 'normal' behaviour is rather different from that for other shield regions around the globe, where thick, fast, lithospheric roots have resulted in an elevated 410 discontinuity (Kumar et al., 2013a). Consistently early passage times, sometimes even close to $\sim 2 \mathrm{~s}$ early, are seen for the $410 \mathrm{~km}$ discontinuity from the stations located in the Himalayan mountain belts and its foothills: (Oreshin et al., 2008, 2011; Kumar et al., 2013a; Kosarev et al., 2013). The continuity of early arrivals is also maintained for most parts of Tibet, south of the Bangong Nuijiang Suture Zone. The northwestern Deccan Volcanic Province and Southern Granulite Terrain show a delay in the passage times of $\sim 1.5 \mathrm{~s}$ compared to stable parts of Indian shield, as both regions are influenced by plumes. The 
northwestern Deccan Volcanic Province shows the strong imprints of Deccan volcanism, and the Southern Granulite Terrain has been affected by Marion plume responsible for separation of Madagascar from India (Kumar et al., 2013a). The other areas which show delayed 410 arrivals are regions close to the eastern coast of India.

In Tibet across various profiles, continuity of the 410 and 660 discontinuities was reported precluding the idea that mantle transition zone is resting ground for detached lithospheric fragments (Yuan et al., 1997; Kind et al., 2002). However, later studies argue in favour of detached lithospheric fragments within the transition zone itself (Singh and Kumar, 2009; Chen and Tseng, 2007).

Olivine and its polymorphs (wadsleyite, $\beta$-spinel and ringwoodite, $\gamma$-spinel) can incorporate small amounts of water into their nominally anhydrous crystal structures. This makes the mantle transition zone a potential water reservoir. There are a number of implications of the effect of water on transition zone discontinuities mainly (a) an elevation of the 410 by changing the thermodynamic stability fields of olivine polymorphs (Wood, 1995; Smyth and Frost, 2002), (b) broadening of transition zone by 20 to $25 \mathrm{~km}$ (Wood, 1995), (c) frequency dependence of amplitudes (van der Meijde et al., 2003), (d) a sharp $520 \mathrm{~km}$ discontinuity if present (Inoue et al., 1998), and (e) hydrous melting can creates low velocity layers atop the 410 with lesser water content above and below (Huang et al., 2005).

Beneath India, there is no compelling evidence for the existence of the $520 \mathrm{~km}$ discontinuity (Kumar et al., 2013a). There are indications of a seismic discontinuity at a depths of $\sim 475 \mathrm{~km}$ beneath Ladakh and Karakoram north of the Indus Suture Zone (Rai et al., 2009b), these were interpreted as arising from the presence of remnants of subducted Indian slab as the depth is well above $520 \mathrm{~km}$. There has so far been little analysis of the frequency dependence of amplitudes of receiver functions for Indian data sets. (Singh and Kumar, 2009) have not found any frequency dependence in northeast India close to Himalayan mountain belts, which appears to rule out possibility of water within the mantle transition zone in this area. A low velocity layer atop the 410 discon- 
tinuity is also reported at few places beneath India (Oreshin et al., 2011; Kosarev et al. 2013; Kumar et al., 2013a), but it remains to be seen how widespread is such a feature, and what the full implications are for water in the transition zone.

\section{2. $660 \mathrm{~km}$ discontinuity}

Early vertical passage times compared with the ak135 reference model (Kennett et al., 1995), sometimes even close to $\sim 2$ s early are seen for the $660 \mathrm{~km}$ discontinuity for regions of Western Tibet, Central India and few parts of Himalaya and Tibet. The early arrivals of 660 near Himalayan collision belt may relate to present day subduction or the the preserved keel of Indian shield (Kosarev et al., 2013), as they are well correlated with the elevation of the 410 discontinuity. Apart from early arrivals or 410 and 660 in the Himalaya, a thick transition zone in the northern part of Indian-subcontinent reflects resting ground for Tethyan slabs within the transition zone itself (Singh and Kumar, 2009). Regions of the Southern Granulite Terrain and South West Deccan Volcanic Province show delayed 660 arrivals, as also observed for 410. The delayed arrivals suggest plume effects above 410 and $660 \mathrm{~km}$, in those regions.

\subsection{X-discontinuity}

Hydration reactions in subduction zones, crystallographic transitions of pyroxene, and the coesite to stishovite transition or exsolution of stishovite from clinopyroxenes containing excess silica, have been used to explain discontinuities observed around 300 km depth (Williams and Revenaugh, 2005; Schmerr et al., 2013; Shen et al., 2014). The intermittent nature of this feature may be due to lateral changes in the fraction of basalt (Schmerr et al., 2013). The reports of this X-discontinuity (Revenaugh and Jordan, 1991) beneath India are few, with possible detection in northeast India (Ramesh et al., 2005) and beneath the Hyderabad station HYB (Bodin et al., 2013). The X-discontinuity inferred from common conversion point stacks of receiver functions in northeast India has been interpreted in terms of melt migration and segregation at these depths (Ramesh et al., 2005). SS precursors also trace such a discontinuity with a shear velocity contrast of 
$\sim 2 \%$ (Deuss and Woodhouse, 2002) beneath India. The presence of the X-discontinuity has implications for the lateral variations and stratification of the mantle, and receiver functions have considerable potential as a tool to track at this depth (Yuan et al., 1997; Wittlinger et al., 2004; Ramesh et al., 2005; Bodin et al., 2013). Careful examination of the seismic data from India may throw more light on the nature of X-discontinuity, which may often be overlooked due to its intermittent nature and low shear impedance contrast (Schmerr et al., 2013).

\section{Summary}

With the aid of the growing body of results from passive seismic studies we have been able to provide a summary description of the crustal properties of much of the Indian subcontinent, and also to characterise the upper mantle beneath.Geographic coverage of peninsular India is good, but information is still limited in the the more northern parts of the cratons, the region of the Indo-Gangetic plains and parts of the Himalayan foothills.

More detailed crustal information is currently available only from the deep seismic sounding coverage, which though extensive is geographically restricted.The exploitation of seismic noise through ambient noise tomography should provide means for augmenting information on crustal structure on a broad scale in a similar way to that used for the AuSREM crustal model in Australia (Kennett and Salmon, 2012). However, this will not be a straightforward task because of rather restrictive data practices by many agencies.

Beneath India the crust is quite variable in its depth beneath the surface and there are indications also of significant changes in character (see supplementary Figure S2 and S3). The cratonic regions generally have crustal thickness in the range 40-45 km, which is typical for cratons in other parts of the world (cf. Kennett and Salmon, 2012). Though there are limited zones, e.g. in the central portion of the Western Dhawar Craton, that have rather thicker crust (more than $55 \mathrm{~km}$ ). The Moho deepens rapidly as the Himalayan collision zone is approached, and the crust reaches its maximum thickness beneath Tibet; the crustal thickness exceeds $75 \mathrm{~km}$ in parts of the Lhasha terrain. The crustal thickness 
map built from the passive seismic and deep seismic sounding studies shows significant deviations from that predicted from global models such as CRUST1.0 (Laske et al., 2013). Such differences are of potential significance whenever crustal corrections have to be made to seismological results.

Although it is difficult to extract a consistent definition of lithospheric thickness from the range of studies that have been undertaken in the Indian region, a number of clear trends emerge. The lithosphere tends to thicken from south to north. The lithosphere beneath the cratonic areas is somewhat thinner than in similar locations around the globe.This has been ascribed to the effects of the rapid motion of India after splitting from Gondwana, but is in contrast with the currently most rapidly moving continent, Australia, where lithospheric thickness estimates exceed $220 \mathrm{~km}$ beneath the Archean Yilgarn craton (Kennett and Salmon, 2012).

The shear-wave splitting results results from body-wave studies show the dominance of strain approximately in the direction of absolute plate motion, with an anisotropic Indian mantle for which the delay times between the split $\mathrm{S}$ phases are close to $1 \mathrm{~s}$. However, the body wave results do not localise the anisotropic zone in depth. The global study by Debayle et al. (2005) of azimuthal anisotropy using surface waves provides indications of two-layer anisotropy beneath India with alignment to absolute plate motion at the base of the lithosphere or in the asthenosphere beneath; though resolution was limited in their study. The only other location with a similar configuration in this study is Australia, with current rapid motion, which shows a distinct change in anisotropic character between 100 and $200 \mathrm{~km}$ depth.

The influence of crustal structure is significant for many tomographic studies, both in body wave tomography and in the frequency band used in surface wave tomography to study the lithospheric mantle and the asthenosphere below. Our results for the Indian subcontinent indicate the need for improved crustal models built from direct observations, rather than assigned by analogy with regions with a similar geological environment. This will be an ongoing task. 
Acknowledgements: We thank M. Ravi Kumar and R. K. Chadha for useful discussions at different points of time. We thank M. Ravi Kumar and R. K. Chadha for useful discussions at different points of time. The study is supported by a grant from Ministry of Earth Sciences (MOES), IITKGP/CKH. We thank Stewart Fishwick and an anonymous reviewer for their valuable comments and suggestions while helped us to improve the manuscript substancially.

\section{References}

Acton, C.E., Priestley, K., Mitra, S., Gaur, V.K., 2011. Crustal structure of the Darjeeling-Sikkim Himalaya and southern Tibet. Geophys. J. Int. 184, 829-852. doi:10.1111/j.1365-246X.2010.04868.x. Ammon, C.J., Randall, G.E., Zandt, G., 1990. On the nonuniqueness of receiver function inversions. J. Geophys. Res. 95, 15303-15318. doi:10.1029/JB095iB10p15303.

Artemieva, I., 2011. The Lithosphere: An interdisciplinary approach. Cambridge University Press.

Ayarza, P., Palomeras, I., Carbonell, R., Afonso, J., Simancas, F., 2010. A wide-angle upper mantle reflector in $\{\mathrm{SW}\}$ iberia: Some constraints on its nature. Phys. Earth Planet. Inter. 181, 88 - 102. doi:10.1016/j.pepi.2010.05.004.

Bai, L., Tian, X., Ritsema, J., 2010. Crustal structure beneath the Indochina peninsula from teleseismic receiver functions. Geophys. Res. Lett. 37, doi:10.1029/2010GL044874.

Barruol, G., Hoffmann, R., 1999. Upper mantle anisotropy beneath the Geoscope stations. J. Geophys. Res. 104, 10757-10773. doi:10.1029/1999JB900033.

Becker, T.W., Faccenna, C., 2011. Mantle conveyor beneath the Tethyan collisional belt. Earth Planet. Sci. Lett. 310, 453-461. doi:10.1016/j.epsl.2011.08.021.

Behera, L., Sain, K., Reddy, P.R., 2004. Evidence of underplating from seismic and gravity studies in the Mahanadi delta of eastern India and its tectonic significance. J. Geophys. Res. 109, doi:10.1029/2003JB002764.

Behera, L., 2011. Crustal tomographic imaging and geodynamic implications toward south of southern granulite terrain (sgt), india. Earth Planet. Sci. Lett. 309, 166 - 178. doi:10.1016/j.epsl.2011.04.033.

Berkner, L.V., 1959. The need for fundamental research in seismology: Report of the panel of seismic improvement. Washington, D.C., U.S. Department of State .

Bhattacharya, S.N., Suresh, G., Mitra, S., 2009. Lithospheric S-wave velocity structure of the Bastar craton, Indian peninsula, from surface-wave phase-velocity measurements. Bull. Seismol. Soc. Am. 99, 2502-2508. doi:10.1785/0120080360. 
Bodin, T., Yuan, H., Romanowicz, B., 2013. Inversion of receiver functions without deconvolution application to the Indian craton. Geophys. J. Int. 13. doi:10.1093/gji/ggt431.

Bodri, L., Bodri, B., 1985. On the correlation between heat flow and crustal thickness. Tectonophysics 120, 69-81. doi:10.1016/0040-1951(85)90087-3.

Borah, K., Rai, S., Gupta, S., Prakasam, K., Kumar, S., Sivaram, K., 2014a. Preserved and modified mid-archean crustal blocks in dharwar craton: Seismological evidence. Precambrian Research 246, 16 - 34. doi:10.1016/j.precamres.2014.02.003.

Borah, K., Rai, S.S., Priestley, K., Gaur, V.K., 2014b. Complex shallow mantle beneath the dharwar craton inferred from rayleigh wave inversion. Geophys. J. Int. 198, 1055-1070. doi:10.1093/gji/ggu185.

Bostock, M.G., 1998. Mantle stratigraphy and evolution of the Slave province. J. Geophys. Res. 103, 21183-21200. doi:10.1029/98JB01069.

Burdick, L.J., Langston, C.A., 1977. Modeling crustal structure through the use of converted phases in teleseismic body-wave forms. Bull. Seismol. Soc. Am. 67, 677-691.

Caldwell, W.B., Klemperer, S.L., Lawrence, J.F., Rai, S.S., Ashish, 2013. Characterizing the Main Himalayan Thrust in the Garhwal Himalaya, India with receiver function CCP stacking. Earth Planet. Sci. Lett. 367, 15-27. doi:10.1016/j.epsl.2013.02.009.

Capitanio, F.A., Morra, G., Goes, S., Weinberg, R.F., Moresi, L., 2013. India-Asia convergence driven by the subduction of the Greater Indian continent. Nature Geoscience 367, 136-139. doi:10.1038/ngeo725.

Chen, W.P., Ozalaybey, S., 1998. Correlation between seismic anisotropy and Bouguer gravity anomalies in Tibet and its implications for lithospheric structures. Geophys. J. Int. 135, 93-101. doi:10.1046/j.1365-246X.1998.00611.x.

Chen, W.P., Tseng, T.L., 2007. Small 660-km seismic discontinuity beneath Tibet implies resting ground for detached lithosphere. J. Geophys. Res. 112, doi:10.1029/2006JB004607.

Chen, Y., Niu, F., Liu, R., Huang, Z., Tkali, H., Sun, L., Chan, W., 2010. Crustal structure beneath China from receiver function analysis. J. Geophys. Res. 115, doi:10.1029/2009JB006386.

Chenet, A.L., Quidelleur, X., Fluteau, F., Courtillot, V., Bajpai, S., 2007. ${ }^{40} \mathrm{~K}^{40}$ Ar dating of the main Deccan large igneous province: Further evidence of KTB age and short duration. Earth Planet. Sci. Lett. 263, 1-15. doi:10.1016/j.epsl.2007.07.011.

Christensen, N.I., Mooney, W.D., 1995. Seismic velocity structure and composition of the continental crust: A global view. J. Geophys. Res. 100, 9761-9788. doi:10.1029/95JB00259.

Clayton, R.W., Wiggins, R.A., 1976. Source shape estimation and deconvolution of teleseismic body waves. Geophys. J. Int. 47, 151-177. doi:10.1111/j.1365-246X.1976.tb01267.x.

Copley, A., Avouac, J.P., Royer, J.Y., 2010. India-Asia collision and the Cenozoic slowdown of the Indian plate: Implications for the forces driving plate motions. J. Geophys. Res. 115, . doi:10.1029/2009JB006634. 
Debayle E., Kennett B. Priestley K., 2011 Global azimuthal seismic anisotropy: the unique plate-motion deformation of Australia, Nature, 433, 509-512.

Deuss, A., Woodhouse, J.H., 2002. A systematic search for mantle discontinuities using ss-precursors. Geophys. Res. Lett. 29, 90-1-90-4. doi:10.1029/2002GL014768.

Devi, E.U., Kumar, P., Kumar, M.R., 2011. Imaging the Indian lithosphere beneath the eastern Himalayan region. Geophys. J. Int. 187, 631-641. doi:10.1111/j.1365-246X.2011.05185.x.

Dobmeier, C.J., Raith, M.M., 2003. Crustal architecture and evolution of the eastern ghats belt and adjacent regions of india. Geological Society, London, Special Publications 206, 145-168. doi:10.1144/GSL.SP.2003.206.01.09

Ford, H.A., Fischer, K.M., Abt, D.L., Rychert, C.A., Elkins-Tanton, L.T., 2010. The lithosphereasthenosphere boundary and cratonic lithospheric layering beneath australia from sp wave imaging. Earth Planet. Sci. Lett. 300, 299-310. doi:10.1016/j.epsl.2010.10.007.

Frederiksen, A.W., Bostock, M.G., 2000. Modelling teleseismic waves in dipping anisotropic structures. Geophys. J. Int. 141, 401-412. doi:10.1046/j.1365-246x.2000.00090.x.

Gaur, V., Priestley, K., 1997. Shear wave velocity structure beneath the archaean granites around Hyderabad, inferred from receiver function analysis. Proc. Indian Acad. Sci. - Earth and Planetary Sciences 106, 1-8. doi:10.1007/BF02841745.

Gu, Y.J., Dziewonski, A.M., Ekstrm, G., 2001. Preferential detection of the Lehmann discontinuity beneath continents. Geophys. Res. Lett. 28, 4655-4658. doi:10.1029/2001GL013679.

Gung, Y., Panning, M., Romanowicz, B., 2003. Global anisotropy and the thickness of continents. Nature 422, 707-711. doi:10.1038/nature01559.

Gupta, S., Rai, S.S., Prakasam, K.S., Srinagesh, D., Bansal, B.K., Chadha, R.K., Priestley, K., Gaur, V.K., 2003. The nature of the crust in southern India: Implications for Precambrian crustal evolution. Geophys. Res. Lett. 30, doi:10.1029/2002GL016770.

Hales, A., 1969. A seismic discontinuity in the lithosphere. Earth Planet. Sci. Lett. 7, $44-46$. doi:10.1016/0012-821X(69)90009-0.

Hazarika, D., Arora, B., Bora, C., 2012. Crustal structure and deformation in the northeast IndiaAsia collision zone: constraints from receiver function analysis. Geophys. J. Int. 188, $737-749$. doi:10.1111/j.1365-246X.2011.05267.x.

Hazarika, D., Kumar, N., Yadav, D., 2013a. Crustal thickness and Poissons ratio variations across the northwest Himalaya and eastern Ladakh. Acta Geophysica 61, 905-922. doi:10.2478/s11600-013-0128$\mathrm{y}$.

Hazarika, D., Yadav, D., Sriram, V., Rai, A., 2013b. Upper mantle anisotropy beneath northeast indiaasia collision zone from shear-wave splitting analysis. Int. J. Earth Sci. , 1-16doi:10.1007/s00531013-0922-4. 
He, C., Santosh, M., Chen, X., Li, X., 2014. Crustal growth and tectonic evolution of the tianshan orogenic belt, $\{\mathrm{NW}\}$ china: A receiver function analysis. J. Geodyn. 75, 41-52. doi:10.1016/j.jog.2014.02.004.

Heintz, M., Kumar, V.P., Gaur, V.K., Priestley, K., Rai, S.S., Prakasam, K.S., 2009. Anisotropy of the Indian continental lithospheric mantle. Geophys. J. Int. 179, 1341-1360. doi:10.1111/j.1365246X.2009.04395.x.

Heit, B., Yuan, X., Bianchi, M., Kind, R., Gossler, J., 2010. Study of the lithospheric and uppermantle discontinuities beneath eastern Asia by SS precursors. Geophys. J. Int. 183, $252-266$. doi:10.1111/j.1365-246X.2010.04714.x.

Huang, X., Xu, Y., Karato, S.I., 2005. Water content in the transition zone from electrical conductivity of wadsleyite and ringwoodite. Nature 434, 746-749. doi:10.1038/nature03426.

Inoue, T., Weidner, D.J., Northrup, P.A., Parise, J.B., 1998. Elastic properties of hydrous ringwoodite (-phase) in $\mathrm{Mg}_{2} \mathrm{SiO}_{4}$. Earth Planet. Sci. Lett. 160, 107-113. doi:10.1016/S0012-821X(98)00077-6.

Jagadeesh, S., Rai, S., 2008. Thickness, composition, and evolution of the Indian Precambrian crust inferred from broadband seismological measurements. Precambrian Research 162, 4-15. doi:10.1016/j.precamres.2007.07.009.

Jordan, T.H., 1988. Structure and formation of the continental tectosphere. J. Petro. Specialvolume, 11-37. doi:10.1093/petrology/Specialvolume.1.11.

Jordan, T.H., Frazer, L.N., 1975. Crustal and upper mantle structure from Sp phases. J. Geophys. Res. 80, 1504-1518. doi:10.1029/JB080i011p01504.

Julià, J., Jagadeesh, S., Rai, S.S., Owens, T.J., 2009. Deep crustal structure of the Indian shield from joint inversion of $\mathrm{P}$ wave receiver functions and Rayleigh wave group velocities: Implications for Precambrian crustal evolution. J. Geophys. Res. 114, doi:10.1029/2008JB006261.

Kaila, K., Chowdhury, K.R., Reddy, P., Krishna, V., Narain, H., Subbotin, S., Sollogub, V., Chekunov, A., Kharetchko, G., Lazarenko, M., et al., 1979. Crustal structure along Kavali-Udipi profile in the Indian peninsular shield from deep seismic sounding. J. Geo. Soc. India 20, 307.

Kaila, K., Krishna, V., Mall, D., 1981a. Crustal structure along Mehmadabad-Billimora profile in the Cambay basin, India, from deep seismic soundings. Tectonophysics 76, 99-130. doi:10.1016/00401951(81)90255-9.

Kaila, K., Murty, P., Rao, V., Venkateswarlu, N., 1990. Deep seismic sounding in the Godavari graben and Godavari (coastal) basin, India. Tectonophysics 173, 307-317. doi:10.1016/0040-1951(90)90226-X.

Kaila, K., Rao, P.K., 1986. Crustal structure along khajuria kalanrahatgaonbetul, multaipulgaon profile across narmadason lineament from deep seismic soundings, in: Kaila, K., Tewari, H. (Eds.), Deep Seismic Sounding and Crustal Tectonics. AEG Publication, India, pp. 43-59.

Kaila, K., Reddy, P., Dixit, M., Rao, P., 1985. Crustal structure across the narmada-son lineament, 
central india, from deep seismic soundings. J. Geol. Soc. India 26, 465-480.

Kaila, K., Tewari, H., Chowdhury, K.R., Rao, V., Sridhar, A., Mall, D., 1987. Crustal structure of the northern part of the Proterozoic Cuddapah basin of India from deep seismic soundings and gravity data. Tectonophysics 140, 1-12. doi:10.1016/0040-1951(87)90136-3.

Kaila, K., Tewari, H., Sarma, P., 1981b. Crustal structure from deep seismic sounding studies along Navibandar-amreli profile in Saurashtra, India. Deccan Volcanism and related basalt provinces in other parts of the world. Mem. Geol. Soc. India , 218-232.

Kaila, K.L., 1981. Structure and Seismotectonics of the Himalaya-Pamir Hindukush Region and the Indian Plate Boundary. American Geophysical Union. doi:10.1029/GD003p0272.

Kaila, K.L., Krishna, V.G., 1992. Deep seismic sounding studies in India and major discoveries. Curr. Sci. $62,117-154$.

Kaila, K.L., Rao, I.B.P., Rao, P.K., Rao, N.M., Krishna, V.G., Sridhar, A.R., 1989. DSS Studies over Deccan Traps along the Thuadara-Sendhwa-Sindad Profile, across Narmada-Son Lineament, India. American Geophysical Union. doi:10.1029/GM051p0127.

Kaila, K.L., Reddy, P.R., Dixit, M.M., Lazrenko, M.A., 1981c. Deep crustal structure at Koyna, Maharashtra indicated by deep seismic soundings. J. Geo. Soc. India 22, 1-16.

Kaila, K.L., Reddy, P.R., Mall, D.M., Venkateswarlu, N., Krishna, V.G., Prasad, A.S.S.S.R.S., 1992. Crustal structure of the west Bengal basin, India from deep seismic sounding investigations. Geophys. J. Int. 111, 45-66. doi:10.1111/j.1365-246X.1992.tb00554.x.

Karato, S.I., 2012. On the origin of the asthenosphere. Earth Planet. Sci. Lett. 321322,95 - 103. doi:10.1016/j.epsl.2012.01.001.

Kawakatsu, H., Kumar, P., Takei, Y., Shinohara, M., Kanazawa, T., Araki, E., Suyehiro, K., 2009. Seismic evidence for sharp lithosphere-asthenosphere boundaries of oceanic plates. Science 324, 499502. doi:10.1126/science.1169499.

Kayal, J., Srivastava, V., Kumar, P., Chatterjee, R., Khan, P., 2011. Evaluation of crustal and upper mantle structures using receiver function analysis: ISM broadband observatory data. J. Geo. Soc. India 78, 76-80. doi:10.1007/s12594-011-0069-5.

Kind, R., Kosarev, G.L., Petersen, N.V., 1995. Receiver functions at the stations of the German regional seismic network (GRSN). Geophys. J. Int. 121, 191-202. doi:10.1111/j.1365-246X.1995.tb03520.x.

Kennett B.L.N., Engdahl E.R., Buland R., 1995. Constraints on seismic velocities in the Earth from travel times, Geophys. J. Int., 122, 108-124.

Kennett, B., Widiyantoro, S., 1999. A low seismic wavespeed anomaly beneath northwestern india: a seismic signature of the deccan plume? Earth Planet. Sci. Lett. 165, 145 - 155. doi:10.1016/S0012821X(98)00260-X.

Kennett B.L.N., Salmon M., 2012. AuSREM: Australian seismological reference model, Austral. J. 
Earth Sci., 59, 1091-1103. doi:10.1080/08120099.2012.736406

Kind, R., Vinnik, L., 1988. The upper-mantle discontinuities underneath the GRF array from P-to-S converted phases. J. Geophys. 62, 138-147.

Kind, R., Yuan, X., Saul, J., Nelson, D., Sobolev, S.V., Mechie, J., Zhao, W., Kosarev, G., Ni, J., Achauer, U., Jiang, M., 2002. Seismic images of crust and upper mantle beneath Tibet: Evidence for Eurasian plate subduction. Science 298, 1219-1221. doi:10.1126/science.1078115.

Kiselev, S., Vinnik, L., Oreshin, S., Gupta, S., Rai, S.S., Singh, A., Kumar, M.R., Mohan, G., 2008. Lithosphere of the Dharwar craton by joint inversion of $\mathrm{P}$ and $\mathrm{S}$ receiver functions. Geophys. J. Int. 173, 1106-1118. doi:10.1111/j.1365-246X.2008.03777.x.

Kosarev, G., Kind, R., Sobolev, S.V., Yuan, X., Hanka, W., Oreshin, S., $1999 . \quad$ Seismic evidence for a detached Indian lithospheric mantle beneath Tibet. Science 283, 1306-1309. doi:10.1126/science.283.5406.1306.

Kosarev, G., Oreshin, S., Vinnik, L., Kiselev, S., Dattatrayam, R., Suresh, G., Baidya, P., 2013. Heterogeneous lithosphere and the underlying mantle of the Indian subcontinent. Tectonophysics 592,175 - 186. doi:10.1016/j.tecto.2013.02.023.

Kumar, K.P., Mohan, G., 2014. Crustal velocity structure beneath Saurashtra, NW India, through waveform modeling: Implications for magmatic underplating. J. Asian Earth Sci. 79, Part A, 173181. doi:10.1016/j.jseaes.2013.09.006.

Kumar, M.R., Mohan, G., 2005. Mantle discontinuities beneath the Deccan volcanic province. Earth Planet. Sci. Lett. 237, 252-263. doi:10.1016/j.epsl.2005.06.034.

Kumar, M.R., Raju, P.S., Devi, E.U., Saul, J., Ramesh, D.S., 2004. Crustal structure variations in northeast India from converted phases. Geophys. Res. Lett. 31, doi:10.1029/2004GL020576.

Kumar, M.R., Saikia, D., Singh, A., Srinagesh, D., Baidya, P., Dattatrayam, R.S., 2013a. Low shear velocities in the sub-lithospheric mantle beneath the Indian shield? J. Geophys. Res. 118, $1142-1155$. doi:10.1002/jgrb.50114.

Kumar, M.R., Saul, J., Sarkar, D., Kind, R., Shukla, A.K., 2001. Crustal structure of the Indian shield: New constraints from teleseismic receiver functions. Geophys. Res. Lett. 28, 1339-1342. doi:10.1029/2000GL012310.

Kumar, M.R., Singh, A., 2008. Evidence for plate motion related strain in the indian shield from shear wave splitting measurements. J. Geophys. Res. 113, doi:10.1029/2007JB005128.

Kumar, N., Kumar, M.R., Singh, A., Raju, P.S., Rao, N.P., 2010. Shear wave anisotropy of the Godavari rift in the south Indian shield: Rift signature or APM related strain? Phys. Earth Planet. Inter. 181, 82-87. doi:10.1016/j.pepi.2010.05.002.

Kumar, P., Ravi Kumar, M., Srijayanthi, G., Arora, K., Srinagesh, D., Chadha, R.K., Sen, M.K., 2013 b. Imaging the lithosphere-asthenosphere boundary of the Indian plate using converted wave techniques. 
J. Geophys. Res., Solid Earth 118, 5307-5319. doi:10.1002/jgrb.50366.

Kumar, P., Yuan, X., Kumar, M.R., Kind, R., Li, X., Chadha, R.K., 2007. The rapid drift of the Indian tectonic plate. Nature 449, 894-897. doi:10.1038/nature06214.

Kumar, T.V., Jagadeesh, S., Rai, S., 2012. Crustal structure beneath the ArcheanProterozoic terrain of north India from receiver function modeling. J. Asian Earth Sci. 58, 108-118. doi:10.1016/j.jseaes.2012.06.015.

Kurita, T., 1973. Regional variations in the structure of the crust in the central United States from P-wave spectra. Bull. Seismol. Soc. Am. 63, 1663-1687.

Langston, C.A., 1979. Structure under Mount Rainier, Washington, inferred from teleseismic body waves. J. Geophys. Res. 84, 4749-4762. doi:10.1029/JB084iB09p04749.

Laske, G., Masters, G., Ma, Z. Pasyanos, M. 2013. Update on CRUST1.0 - A 1-degree Global Model of Earth's Crust Geophys. Res. Abstracts, 15, Abstract EGU2013-2658.

Levin, V., Park, J., 1997. Crustal anisotropy in the Ural mountains foredeep from teleseismic receiver functions. Geophys. Res. Lett. 24, 1283-1286. doi:10.1029/97GL51321.

Li, Y., Gao, M., Wu, Q., 2014. Crustal thickness map of the Chinese mainland from teleseismic receiver functions. Tectonophysics 611, 51-60. doi:10.1016/j.tecto.2013.11.019.

Li, Y.H., Tian, X.B., Wu, Q.J., Zeng, R.S., Zhang, R.Q., 2006. The Poisson ratio and crustal structure of the central Tibetan plateau inferred from Indepth-III teleseismic waveforms: Geological and geophysical implications. Chinese J. Geophys. 49, 924-931. doi:10.1002/cjg2.913.

Li, Y.H., Wu, Q.J., Tian, X.B., 2009. Crustal structure in the Yunnan region determined by modeling receiver functions. Chinese J. Geophys. 52, 67-80.

Madhusudhan Rao, K., Ravi Kumar, M., Singh, A., Rastogi, B.K., 2013. Two distinct shear wave splitting directions in the northwestern Deccan volcanic province. J. Geophys. Res. 118, 5487-5499. doi:10.1002/2013JB010644.

Mandal, P., 2011. Upper mantle seismic anisotropy in the intra-continental Kachchh rift zone, Gujarat, India. Tectonophysics 509, 81-92. doi:10.1016/j.tecto.2011.05.013.

Mandal, P., 2012. Passivesource seismic imaging of the crust and upper mantle beneath the $2001 \mathrm{mw} 7.7$ bhuj earthquake region, gujarat, india. Bull. Seismol. Soc. Am. 102, 252-266. doi:10.1785/0120110116.

Mareschal, J.C., Jaupart, C., 2013. Radiogenic heat production, thermal regime and evolution of continental crust. Tectonophysics 609, 524-534. doi:10.1016/j.tecto.2012.12.001.

McKenzie, D., Priestley, K., 2008. The influence of lithospheric thickness variations on continental evolution. Lithos 102, 1 - 11. doi:10.1016/j.lithos.2007.05.005.

McNamara, D.E., Owens, T.J., 1993. Azimuthal shear wave velocity anisotropy in the Basin and Range province using moho Ps converted phases. J. Geophys. Res. 98, 12003-12017. doi:10.1029/93JB00711. Meert, J.G., Pandit, M.K., Pradhan, V.R., Banks, J., Sirianni, R., Stroud, M., Newstead, B., Gifford, J., 
2010. Precambrian crustal evolution of peninsular India: A 3.0 billion year odyssey. J. Asian Earth Sci. 39, 483-515. doi:10.1016/j.jseaes.2010.04.026. tectonics of the Indian Subcontinent.

van der Meijde, M., Marone, F., Giardini, D., van der Lee, S., 2003. Seismic evidence for water deep in earth's upper mantle. Science 300, 1556-1558. doi:10.1126/science.1083636.

Mitra, S., Bhattacharya, S.N., Nath, S.K., 2008. Crustal structure of the western Bengal basin from joint analysis of teleseismic receiver functions and Rayleigh-wave dispersion. Bull. Seismol. Soc. Am. 98, 2715-2723. doi:10.1785/0120080141.

Mitra, S., Priestley, K., Bhattacharyya, A.K., Gaur, V.K., 2005. Crustal structure and earthquake focal depths beneath northeastern India and southern Tibet. Geophys. J. Int. 160, $227-248$. doi:10.1111/j.1365-246X.2004.02470.x.

Mitra, S., Priestley, K., Gaur, V.K., Rai, S.S., 2006. Shear-wave structure of the south indian lithosphere from rayleigh wave phase-velocity measurements. Bull. Seismol. Soc. Am. 96, 1551-1559. doi:10.1785/0120050116

Mohan, G., Kumar, M.R., 2004. Seismological constraints on the structure and composition of western Deccan volcanic province from converted phases. Geophys. Res. Lett. 31, doi:10.1029/2003GL018920.

Mohorovičić, A., 1910. Jahrbuch des meteorologischen Observatoriums in Zagreb (Agram) für das jahr 1909, English translation, 1992. Earthquake of 1909 october 8. Geofizika 9, 3-55.

Muller, R.D., 2011. Earth science: Plate motion and mantle plumes. Nature 475, 40-41. doi:10.1038/475040a.

Murty, A., Sain, K., Tewari, H., Prasad, B.R., 2008. Crustal velocity inhomogeneities along the HirapurMandla profile, central India and its tectonic implications. J. Asian Earth Sci. 31, 533-545. doi:10.1016/j.jseaes.2007.09.003.

Nagaraju, P., Ray, L., Ravi, G., Akkiraju, V., Roy, S., 2012. Geothermal investigations in the upper Vindhyan sedimentary rocks of Shivpuri area, central India. J. Geo. Soc. India 80, 39-47. doi:10.1007/s12594-012-0116-x.

Negi, J., Pandey, O., Agrawal, P., 1986. Super-mobility of hot indian lithosphere. Tectonophysics 131, 147-156. doi:10.1016/0040-1951(86)90272-6.

Oldham, R.D., 1899. Report on the great earthquake of June 12, 1897. Mem. Geol. Surv. India $29,379$.

O'Reilly, S.Y., Griffin, W., 2010. The continental lithosphereasthenosphere boundary: Can we sample it? Lithos 120, 1-13. doi:10.1016/j.lithos.2010.03.016.

O'Reilly, S.Y., Griffin, W., 2013. Moho vs crustmantle boundary: Evolution of an idea. Tectonophysics 609, 535-546. doi:10.1016/j.tecto.2012.12.031.

Oreshin, S., Kiselev, S., Vinnik, L., Prakasam, K.S., Rai, S.S., Makeyeva, L., Savvin, Y., 2008. Crust and mantle beneath western Himalaya, Ladakh and western Tibet from integrated seismic data. Earth Planet. Sci. Lett. 271, 75-87. doi:10.1016/j.epsl.2008.03.048. 
Oreshin, S., Vinnik, L., Kiselev, S., Rai, S., Prakasam, K., Treussov, A., 2011. Deep seismic structure of the Indian shield, western Himalaya, Ladakh and Tibet. Earth Planet. Sci. Lett. 307, 415-429. doi:10.1016/j.epsl.2011.05.016.

Owens, T.J., 1987. Crustal structure of the Adirondacks determined from broadband teleseismic waveform modeling. J. Geophys. Res. 92, 6391-6401. doi:10.1029/JB092iB07p06391.

Owens, T.J., Zandt, G., 1985. The response of the continental crust-mantle boundary observed on broadband teleseismic receiver functions. Geophys. Res. Lett. 12, 705-708. doi:10.1029/GL012i010p00705.

Owens, T.J., Zandt, G., 1997. Implications of crustal property variations for models of Tibetan plateau evolution. Nature 387, 37-43. doi:10.1038/387037a0.

Owens, T.J., Zandt, G., Taylor, S.R., 1984. Seismic evidence for an ancient rift beneath the Cumberland plateau, Tennessee: A detailed analysis of broadband teleseismic P waveforms. J. Geophys. Res. 89, 7783-7795. doi:10.1029/JB089iB09p07783.

Pandey, S., Yuan, X., Debayle, E., Priestley, K., Kind, R., Tilmann, F., Li, X., 2014. A 3d shear-wave velocity model of the upper mantle beneath china and the surrounding areas. Tectonophysics 633, 193 - 210. doi:10.1016/j.tecto.2014.07.011.

Pathak, A., Kumar, M.R., Sarkar, D., 2006. Seismic structure of Sri Lanka using receiver function analysis: A comparison with other high-grade Gondwana terrains. Gondwana Research 10, $198-202$. doi:10.1016/j.gr.2005.10.006.

Patro, P.K., Sarma, S.V.S., 2009. Lithospheric electrical imaging of the Deccan trap covered region of western India. J. Geophys. Res. 114, doi:10.1029/2007JB005572.

Phinney, R.A., 1964. Structure of the earth's crust from spectral behavior of long-period body waves. J. Geophys. Res. 69, 2997-3017. doi:10.1029/JZ069i014p02997.

Powers, P., 1996. Structure and shortening of the Kangra and Dehra Dun re-entrants, sub-Himalaya, India, in: Master's thesis. Corvallis, Oregon State University, p. 66.

Powers, P.M., Lillie, R.J., Yeats, R.S., 1998. Structure and shortening of the Kangra and Dehra Dun re-entrants, sub-Himalaya, India. Geol. Soc. Am. Bull. 110, 1010-1027. doi:10.1130/00167606(1998)110¡1010:SASOTK¿2.3.CO;2.

Prasad, B., Rao, V., 2006. Deep seismic reflection study over the Vindhyans of Rajasthan: Implications for geophysical setting of the basin. J. Asian Earth Sci. 115, 135-147. doi:10.1007/BF02703030.

Prasad, B.R., Klemperer, S.L., Rao, V.V., Tewari, H., Khare, P., 2011. Crustal structure beneath the sub-Himalayan foldthrust belt, Kangra recess, northwest India, from seismic reflection profiling: Implications for late Paleoproterozoic orogenesis and modern earthquake hazard. Earth Planet. Sci. Lett. 308, 218-228. doi:10.1016/j.epsl.2011.05.052.

Priestley, K., McKenzie, D., 2013. The relationship between shear wave velocity, temperature, attenuation and viscosity in the shallow part of the mantle. Earth Planet. Sci. Lett. 381, 78-91. 
doi:10.1016/j.epsl.2013.08.022.

Priestley, K., Tilmann, F., 2009. Relationship between the upper mantle high velocity seismic lid and the continental lithosphere. Lithos 109, 112 - 124. doi:10.1016/j.lithos.2008.10.021. continental Lithospheric Mantle: The Petro-Geophysical Approach The Structure of the Lithosphere: the petrogeophysical approach.

Prodehl, C., Kennett, B., Artemieva, I.M., Thybo, H., 2013. 100 years of seismic research on the Moho. Tectonophysics 609, 9 - 44. doi:10.1016/j.tecto.2013.05.036.

Rai, A., Gaur, V.K., Rai, S.S., Priestley, K., 2009a. Seismic signatures of the pan-African orogeny: implications for southern Indian high-grade terranes. Geophys. J. Int. 176, 518-528. doi:10.1111/j.1365246X.2008.03965.x.

Rai, S., Kumar, T.V., Jagadeesh, S., 2005. Seismic evidence for significant crustal thickening beneath Jabalpur earthquake, 21 May 1997, source region in Narmadason lineament, central India. Geophys. Res. Lett. 32, doi:10.1029/2005GL023580.

Rai, S.S., Priestley, K., Gaur, V.K., Mitra, S., Singh, M.P., Searle, M., 2006. Configuration of the Indian Moho beneath the NW Himalaya and Ladakh. Geophys. Res. Lett. 33, doi:10.1029/2006GL026076.

Rai, S.S., Priestley, K., Suryaprakasam, K., Srinagesh, D., Gaur, V.K., Du, Z., 2003. Crustal shear velocity structure of the south Indian shield. J. Geophys. Res. 108, doi:10.1029/2002JB001776.

Rai, S.S., Suryaprakasam, K., Gaur, V., 2009b. Seismic imaging of the mantle discontinuities beneath India: From Archean cratons to Himalayan subduction zone, in: Gupta, A., Dasgupta, S. (Eds.), Physics and Chemistry of the Earths Interior. Springer New York, pp. 153-161. doi:10.1007/978-14419-0346_4_9.

Ramesh, D., Bharthur, R., Prakasam, K., Srinagesh, D., Rai, S., Gaur, V., 1996. Predominance of plate motion-related strain in the south Indian shield. Curr. Sci 70, 843-847.

Ramesh, D., Bianchi, M., Sharma, S.D., 2010. Images of possible fossil collision structures beneath the eastern Ghats belt, India, from P and S receiver functions. Lithosphere 2, 84-92. doi:10.1130/L70.1.

Ramesh, D.S., Ravi Kumar, M., Uma Devi, E., Solomon Raju, P., Yuan, X., 2005. Moho geometry and upper mantle images of northeast India. Geophys. Res. Lett. 32, doi:10.1029/2005GL022789.

Rao, I.B.P., Murthy, P.R.K., Koteswara Rao, P., Murty, A.S.N., Madhava Rao, N., Kaila, K.L., 1999. Structure of the lower crust revealed by one- and two-dimensional modeling of wide-angle reflections west Bengal basin, India. Pure Appl. Geophys. 156, 701-718. doi:10.1007/s000240050320.

Rao, N.P., Roy S., Arora K., 2013. Deep scientific drilling in Koyna,India - Brain-storming workshop on geological investigations 1920, March 2013. J. Geol. Soc. India 81, 722-723.

Rawlinson, N., Pozgay, S., Fishwick, S., 2010. Seismic tomography: A window into deep earth. Phys. Earth Planet. Inter. 178, 101 - 135. doi:10.1016/j.pepi.2009.10.002.

Reddy, P.R., Murthy, P.R.K., Rao, I.B.M., Mall, D.M., Rao, P.K., 2000. Coincident deep seismic 
refraction and reflection profiling, central India, in: Verma, O.P., Mahadevan, T.M. (Eds.), Research highlights in Earth System Science. Indian Geological Congress, pp. 49-53.

Reddy, P., Rao, V.V., 2003. Deep seismic reflection and refraction/wide-angle reflection studies along Kuppam-Palani transect in the southern granulite terrain of India. Mem. Geol. Surv. India , 79 106, In: Ramakrishnan, M. (Ed.) Tectonics of Southern Granulite Terrane.

Reddy, P., Rao, V.V., 2013. Seismic images of the continental Moho of the Indian shield. Tectonophysics 609, 217-233. doi:10.1016/j.tecto.2012.11.022.

Revenaugh, J., Jordan, T.H., 1991. Mantle layering from ScS reverberations: 2. the transition zone. J. Geophys. Res. 96, 19763-19780. doi:10.1029/91JB01486.

Richter, C., 1958. Elementary Seismology. W. H. Freeman, San Francisco.

Roy, S., Rao, R.U.M., 2000. Heat flow in the Indian shield. J. Geophys. Res. 105, $25587-25604$. doi:10.1029/2000JB900257.

Roy, S.K., Srinagesh, D., Saikia, D., Singh, A., Kumar, M.R., 2012. Seismic anisotropy beneath the eastern Dharwar craton. Lithosphere 4, 259-268. doi:10.1130/L198.1.

Rychert, C.A., Shearer, P.M., 2009. A global view of the lithosphere-asthenosphere boundary. Science 324, 495-498. doi:10.1126/science.1169754.

Saikia, D., Ravi Kumar, M., Singh, A., Mohan, G., Dattatrayam, R.S., 2010. Seismic anisotropy beneath the Indian continent from splitting of direct S waves. J. Geophys. Res. 115, doi:10.1029/2009JB007009.

Sarkar, D., Kumar, M.R., Saul, J., Kind, R., Raju, P.S., Chadha, R.K., Shukla, A.K., 2003. A receiver function perspective of the Dharwar craton (India) crustal structure. Geophys. J. Int. 154, $205-211$. doi:10.1046/j.1365-246X.2003.01970.x.

Saul, J., Kumar, M.R., Sarkar, D., 2000. Lithospheric and upper mantle structure of the Indian shield, from teleseismic receiver functions. Geophys. Res. Lett. 27, 2357-2360. doi:10.1029/1999GL011128.

Schaeffer, A.J., Lebedev, S., 2013. Global shear speed structure of the upper mantle and transition zone. Geophys. J. Int. doi:10.1093/gji/ggt095.

Schmerr, N.C., Kelly, B.M., Thorne, M.S., 2013. Broadband array observations of the $300 \mathrm{~km}$ seismic discontinuity. Geophys. Res. Lett. 40, 841-846. doi:10.1002/grl.50257.

Sharma, S.D., Ramesh, D.S., 2013. Imaging mantle lithosphere for diamond prospecting in southeast India. Lithosphere 5, 331-342. doi:10.1130/L269.1.

Shen, X., Yuan, X., Li, X., 2014. A ubiquitous low-velocity layer at the base of the mantle transition zone. Geophys. Res. Lett. 41, 836-842. doi:10.1002/2013GL058918.

Shen, X., Zhou, H., Kawakatsu, H., 2008. Mapping the upper mantle discontinuities beneath China with teleseismic receiver functions. Earth Planets Space 60, 713-719. doi:10.1186/BF03352819.

Sherrington, H.F., Zandt, G., Frederiksen, A., 2004. Crustal fabric in the Tibetan plateau based on waveform inversions for seismic anisotropy parameters. JGR 109, doi:10.1029/2002JB002345. 
Singh, A., Kumar, M.R., 2009. Seismic signatures of detached lithospheric fragments in the mantle beneath eastern Himalaya and southern Tibet. Earth Planet. Sci. Lett. 288, 279-290. doi:10.1016/j.epsl.2009.09.031.

Singh, A., Kumar, M.R., Kumar, N., Saikia, D., Raju, P.S., Srinagesh, D., Rao, N.P., Sarkar, D., 2012. Seismic signatures of an altered crust and a normal transition zone structure beneath the Godavari rift. Precambrian Research 220221, 1-8. doi:10.1016/j.precamres.2012.07.006.

Singh, A., Kumar, M.R., Raju, P.S., 2007. Mantle deformation in sikkim and adjoining himalaya: Evidences for a complex flow pattern. Phys. Earth Planet. Inter. 164, 232-241. doi:10.1016/j.pepi.2007.07.003.

Singh, A., Kumar, M.R., Raju, P.S., 2010. Seismic structure of the underthrusting Indian crust in Sikkim Himalaya. Tectonics 29, doi:10.1029/2010TC002722.

Singh, A., Kumar, M.R., Raju, P.S., Ramesh, D.S., 2006. Shear wave anisotropy of the northeast Indian lithosphere. Geophys. Res. Lett. 33, doi:10.1029/2006GL026106.

Singh, A., Mercier, J.P., Ravi Kumar, M., Srinagesh, D., Chadha, R.K., 2014. Continental scale body wave tomography of India: Evidence for attrition and preservation of lithospheric roots. Geochem., Geophys., Geosys. 15, 658-675. doi:10.1002/2013GC005056.

Smyth, J.R., Frost, D.J., 2002. The effect of water on the 410-km discontinuity: An experimental study. Geophys. Res. Lett. 29, 123-1-123-4. doi:10.1029/2001GL014418.

Stolk, W., Kaban, M., Beekman, F., Tesauro, M., Mooney, W.D., Cloetingh, S., 2013. High resolution regional crustal models from irregularly distributed data: Application to Asia and adjacent areas. Tectonophysics 602, 55 - 68. doi:10.1016/j.tecto.2013.01.022.

Tandon, A.N., 1992. Seismology in India - an overview upto 1979. Curr. Sci. 62, xx-xx.

Taylor, P., Chadwick, B., Moorbath, S., Ramakrishnan, M., Viswanatha, M., 1984. Petrography, chemistry and isotopic ages of peninsular gneiss, Dharwar acid volcanic rocks and the Chitradurga granite with special reference to the late archean evolution of the Karnataka craton, southern India. Precambrian Research 23, 349 - 375. doi:10.1016/0301-9268(84)90050-0.

Teng, J., Zhang, Z., Zhang, X., Wang, C., Gao, R., Yang, B., Qiao, Y., Deng, Y., 2013. Investigation of the Moho discontinuity beneath the Chinese mainland using deep seismic sounding profiles. Tectonophysics 609, $202-216$. doi:10.1016/j.tecto.2012.11.024.

Tian, X., Zhang, Z., 2013. Bulk crustal properties in NE Tibet and their implications for deformation model. Gondwana Research 24, 548 - 559. doi:10.1016/j.gr.2012.12.024.

Tiwari, K.P., Surve, G., Mohan, G., 2006. Crustal constraints on the uplift mechanism of the western Ghats of india. Geophys. J. Int. 167, 1309-1316. doi:10.1111/j.1365-246X.2006.03093.x.

Vinnik, L., 1977. Detection of waves converted from P to SV in the mantle. Phys. Earth Planet. Inter. 15, 39-45. doi:10.1016/0031-9201(77)90008-5. 
Vinnik, L., Kurnik, E., Farra, V., 2005. Lehmann discontinuity beneath North America: No role for seismic anisotropy. Geophys. Res. Lett. 32, doi:10.1029/2004GL022333.

Vinnik, L., Singh, A., Kiselev, S., Kumar, M.R., 2007. Upper mantle beneath foothills of the western himalaya: subducted lithospheric slab or a keel of the indian shield? Geophys. J. Int. 171, 1162-1171. doi:10.1111/j.1365-246X.2007.03577.x.

Vinnik, L.P., Makeyeva, L.I., Milev, A., Usenko, A.Y., 1992. Global patterns of azimuthal anisotropy and deformations in the continental mantle. Geophys. J. Int. 111, 433-447. doi:10.1111/j.1365246X.1992.tb02102.x.

Wang, C.Y., Lou, H., Silver, P.G., Zhu, L., Chang, L., 2010. Crustal structure variation along $30^{\circ} \mathrm{N}$ in the eastern Tibetan plateau and its tectonic implications. Earth Planet. Sci. Lett. 289, 367-376. doi:10.1016/j.epsl.2009.11.026.

Wessel, P., Smith, W.H.F., 1998. New, improved version of Generic Mapping Tools released. EOS 79, 579-579. doi:10.1029/98EO00426.

Williams, Q., Revenaugh, J., 2005. Ancient subduction, mantle eclogite, and the $300 \mathrm{~km}$ seismic discontinuity. Geology 33, 1-4. doi:10.1130/G20968.1.

Wittlinger, G., Farra, V., Vergne, J., 2004. Lithospheric and upper mantle stratifications beneath Tibet: New insights from Sp conversions. Geophys. Res. Lett. 31, doi:10.1029/2004GL020955.

Wood, B.J., 1995. The effect of $\mathrm{H}_{2} \mathrm{O}$ on the 410-kilometer seismic discontinuity. Science 268, 74-76. doi:10.1126/science.268.5207.74.

Wüstefeld, A., Bokelmann, G., Zaroli, C., Barruol, G., 2008. Splitlab: A shear-wave splitting environment in Matlab. Computers and Geosciences 34, 515-528. doi:10.1016/j.cageo.2007.08.002.

Xiaosong, X., Rui, G., Qiusheng, L., Zhanwu, L., 2009. Moho depth of Qinghai-Tibet plateau revealed by seismic probing. J. Earth Sci. 20, 448-463. doi:10.1007/s12583-009-0037-9.

Xu, Q., Zhao, J., Cui, Z., Pei, S., Liu, H., 2010. Moho offset beneath the central Bangong-Nujiang suture of Tibetan plateau. Chin. Sci. Bull. 55, 607-613. doi:10.1007/s11434-009-0387-9.

Xu, Q., Zhao, J., Pei, S., Liu, H., 2013a. Distinct lateral contrast of the crustal and upper mantle structure beneath northeast tibetan plateau from receiver function analysis. Phys. Earth Planet. Inter. 217, 1 - 9. doi:10.1016/j.pepi.2013.01.005.

Xu, Q., Zhao, J., Pei, S., Liu, H., 2013b. Imaging lithospheric structure of the eastern himalayan syntaxis: New insights from receiver function analysis. J. Geophys. Res. 118, 2323-2332. doi:10.1002/jgrb.50162.

Yin, A., Harrison, T.M., 2000. Geologic evolution of the Himalayan-Tibetan orogen. Annual Rev. Earth Planet Sci. 28, 211 - 280. doi:10.1146/annurev.earth.28.1.211.

Yoshizawa, K., 2014. Radially anisotropic 3-D shear wave structure of the Australian lithosphere and asthenosphere from multi-mode surface waves. Phys. Earth Planet. Inter. 235, 33-48. doi:10.1016/j.pepi.2014.07.008. 
Yuan, H., Romanowicz, B., 2010. Lithospheric layering in the North American craton. Nature 466, 1063-1068. doi:10.1038/nature09332.

Yuan, X., Ni, J., Kind, R., Mechie, J., Sandvol, E., 1997. Lithospheric and upper mantle structure of southern Tibet from a seismological passive source experiment. J. Geophys. Res. 102, 27491-27500. doi:10.1029/97JB02379.

Yue, H., Chen, Y.J., Sandvol, E., Ni, J., Hearn, T., Zhou, S., Feng, Y., Ge, Z., Trujillo, A., Wang, Y., Jin, G., Jiang, M., Tang, Y., Liang, X., Wei, S., Wang, H., Fan, W., Liu, Z., 2012. Lithospheric and upper mantle structure of the northeastern Tibetan plateau. J. Geophys. Res. 117, doi:10.1029/2011JB008545.

Zha, X., Lei, J., 2013. Crustal thickness and Poissons ratio beneath the Yunnan region. Science China Earth Sciences 56, 693-702. doi:10.1007/s11430-013-4583-8.

Zhang, J., Langston, C.A., 1995. Dipping structure under Dourbes, Belgium, determined by receiver function modeling and inversion. Bull. Seismol. Soc. Am. 85, 254-268.

Zhu, L., Kanamori, H., 2000. Moho depth variation in southern California from teleseismic receiver functions. J. Geophys. Res. 105, 2969-2980. doi:10.1029/1999JB900322. 


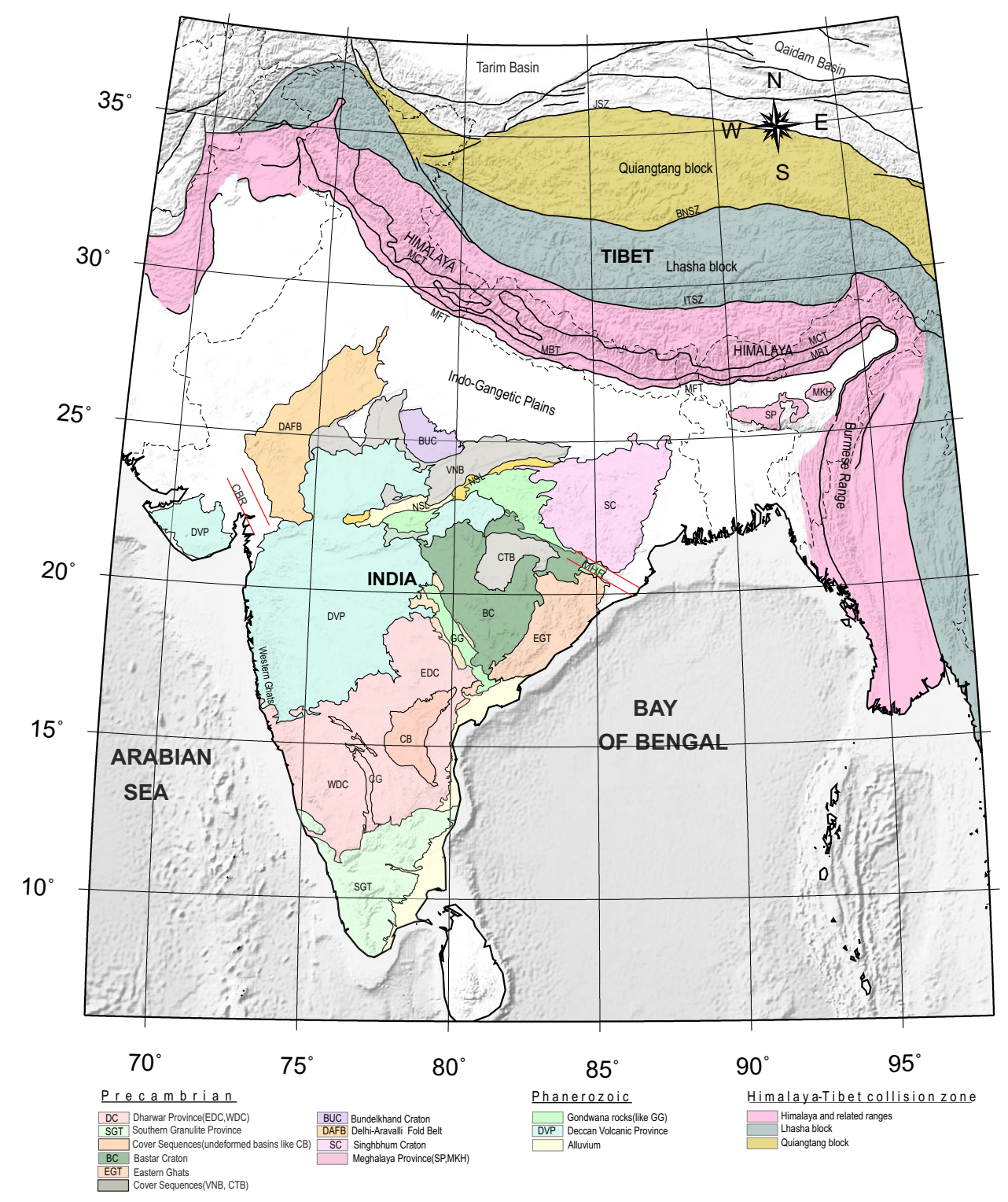

Figure 1: Simplified geological map of India and Tibet: SGT, Southern Granulite Terrain; CG, Closepet Granite; WDC, Western Dharwar craton; EDC, Eastern Dharwar craton; CB, Cuddapah Basin; DVP, Deccan volcanic province; NSL, Narmada-Son Lineament; GG, Godavari Graben; BC, Bastar craton; CTB, Chattishgarh Basin; SC, Singhbhum craton; VNB, Vindhyan Basin; BUC, Bundelkhand craton; DAFB, Delhi-Aravalli Fold Belt; SP, Shillong Plateau; MKH, Mikir Hills; MHR, Mahanadi Rift; CBR, Cambay Rift; MFT, Main Frontal Thrust; MBT, Main Boundary Thrust; MCT, Main Central Thrust; ITSZ, Indus-Tsangpo Suture Zone; BNSZ, Bangong-Nujiang Suture Zone; JSZ, Jinsa Suture Zone. 

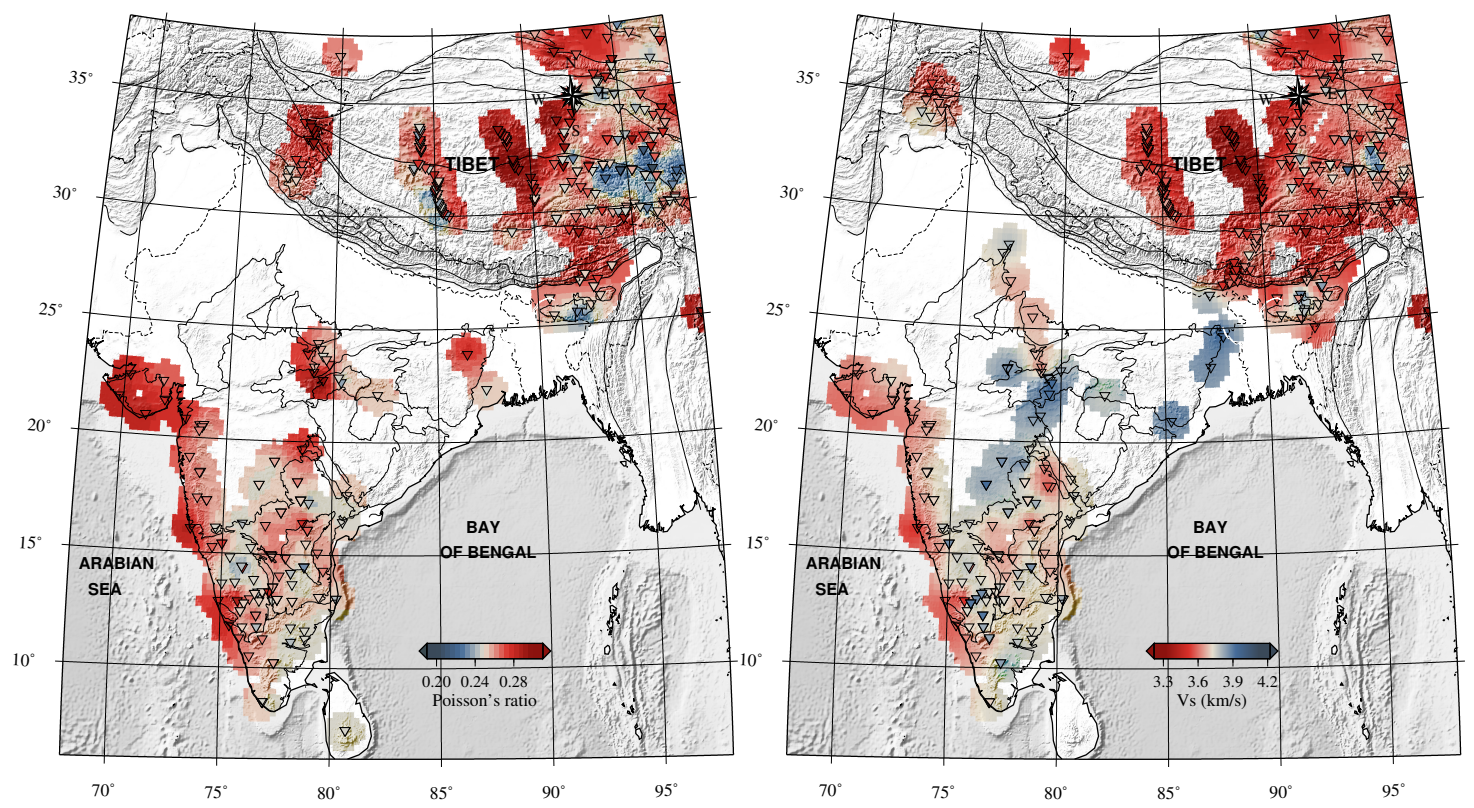

Figure 2: (a) The Poisson's ratio and (b) the average crustal velocity (Vs) from passive seismic stdueies at the stations marked with inverted triangles. The maps are produced using results from Saul et al. (2000); Kumar et al. (2001); Sarkar et al. (2003); Gupta et al. (2003); Kumar et al. (2004); Sherrington et al. (2004); Rai et al. (2003, 2005); Mitra et al. (2005); Li et al. (2006); Tiwari et al. (2006); Pathak et al. (2006); Mitra et al. (2008); Jagadeesh and Rai (2008); Li et al. (2009); Julià et al. (2009); Rai et al. (2009a); Xu et al. (2010); Bai et al. (2010); Chen et al. (2010); Singh et al. (2010); Wang et al. (2010); Acton et al. (2011); Kayal et al. (2011); Singh et al. (2012); Yue et al. (2012); Hazarika et al. (2013a); Xu et al. (2013b,a); Zha and Lei (2013); Borah et al. (2014a); Kumar and Mohan (2014). A total of 457 data points for the Poisson's ratio and 499 data points for Vs are employed (the specific values are presented in Supplementary Table S1). A search radius of $100 \mathrm{~km}$ has been used to initialize the gridding of the crustal data. A nearest neighbour interpolation scheme has been used to produce this and all the subsequent images in the paper (Wessel and Smith, 1998). As ceratin data points may have multiple estimates, the uncertainities in terms of standard deviation are represented in Figure S1. 

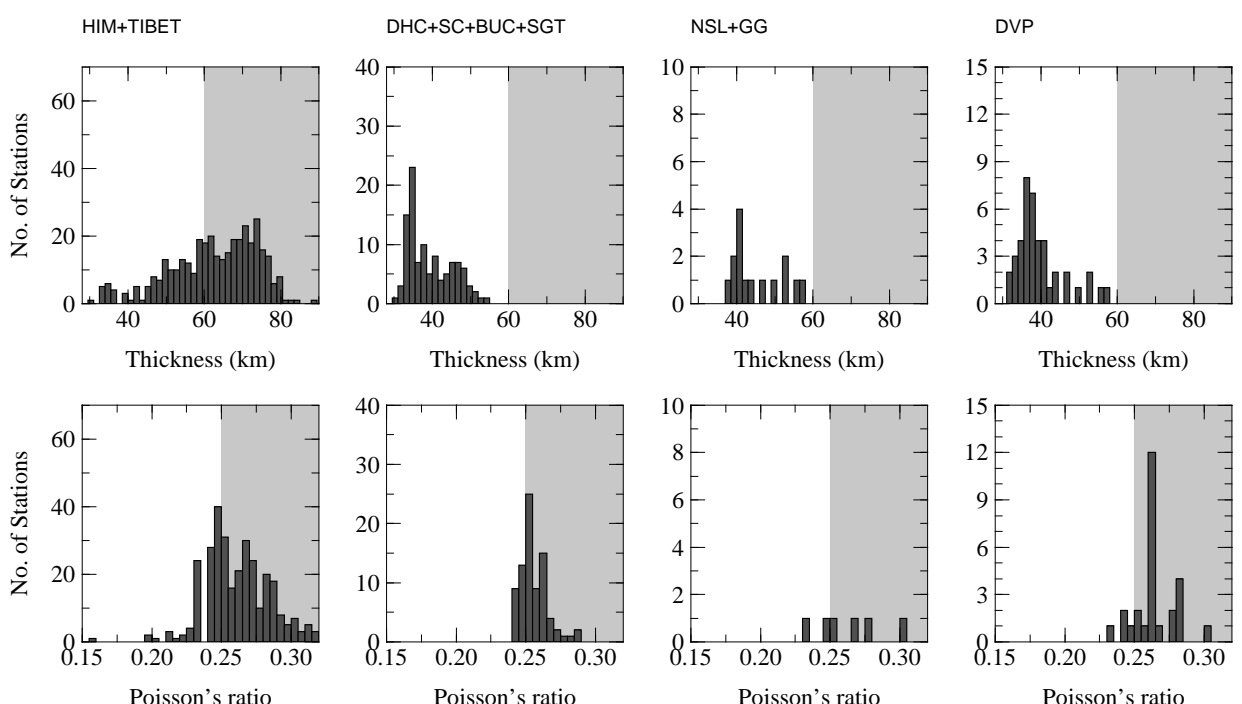

Thickness (km)
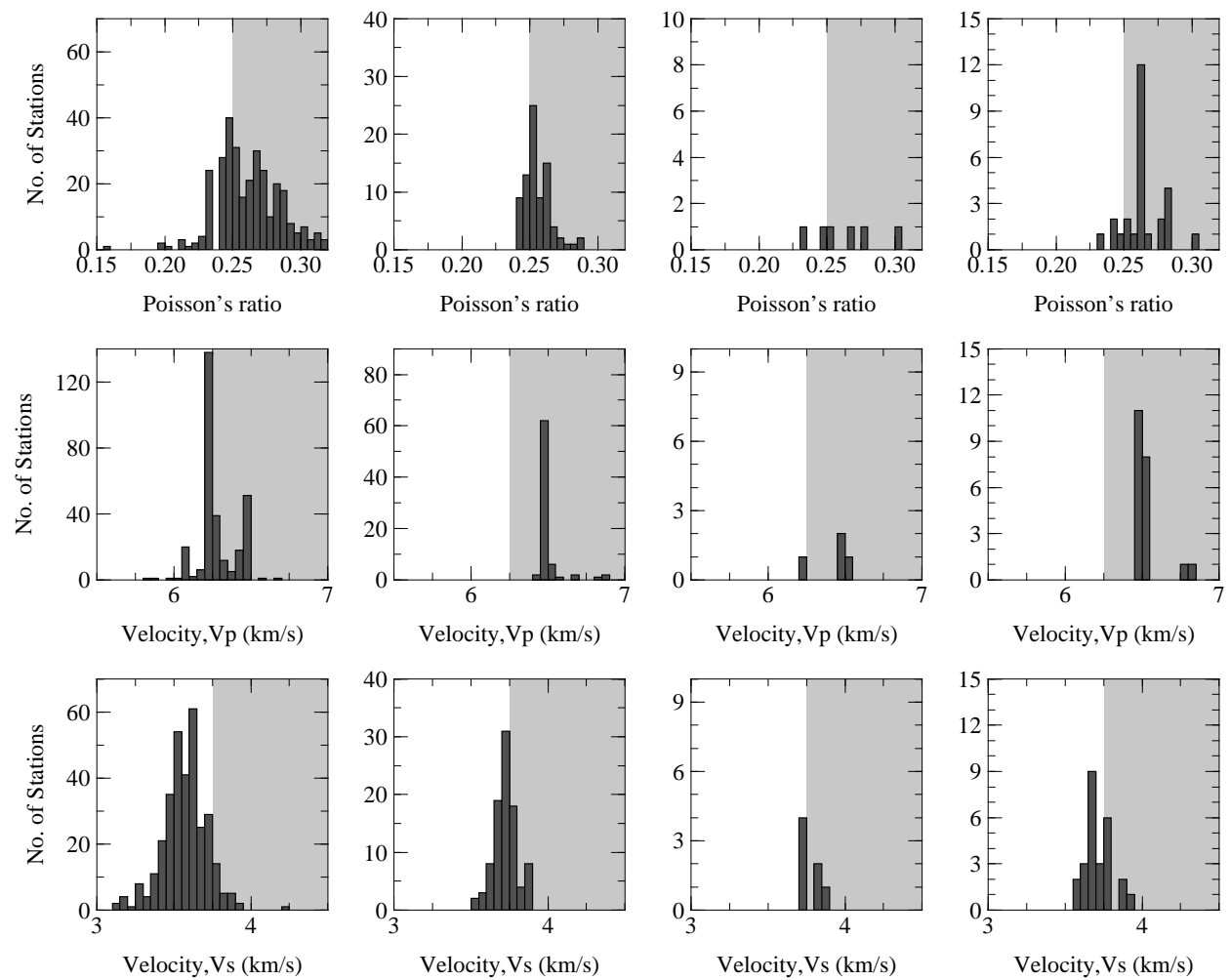

Figure 3: Histograms for crustal parameters, crustal thickness, average Poisson's ratio, average $\mathrm{P}$ velocity, and average $\mathrm{S}$ velocity for specific geological regions. Each box is divided with distinct background colors (e.g., with a split at 0.25 for Poisson's ratio) to ease comparisons. 


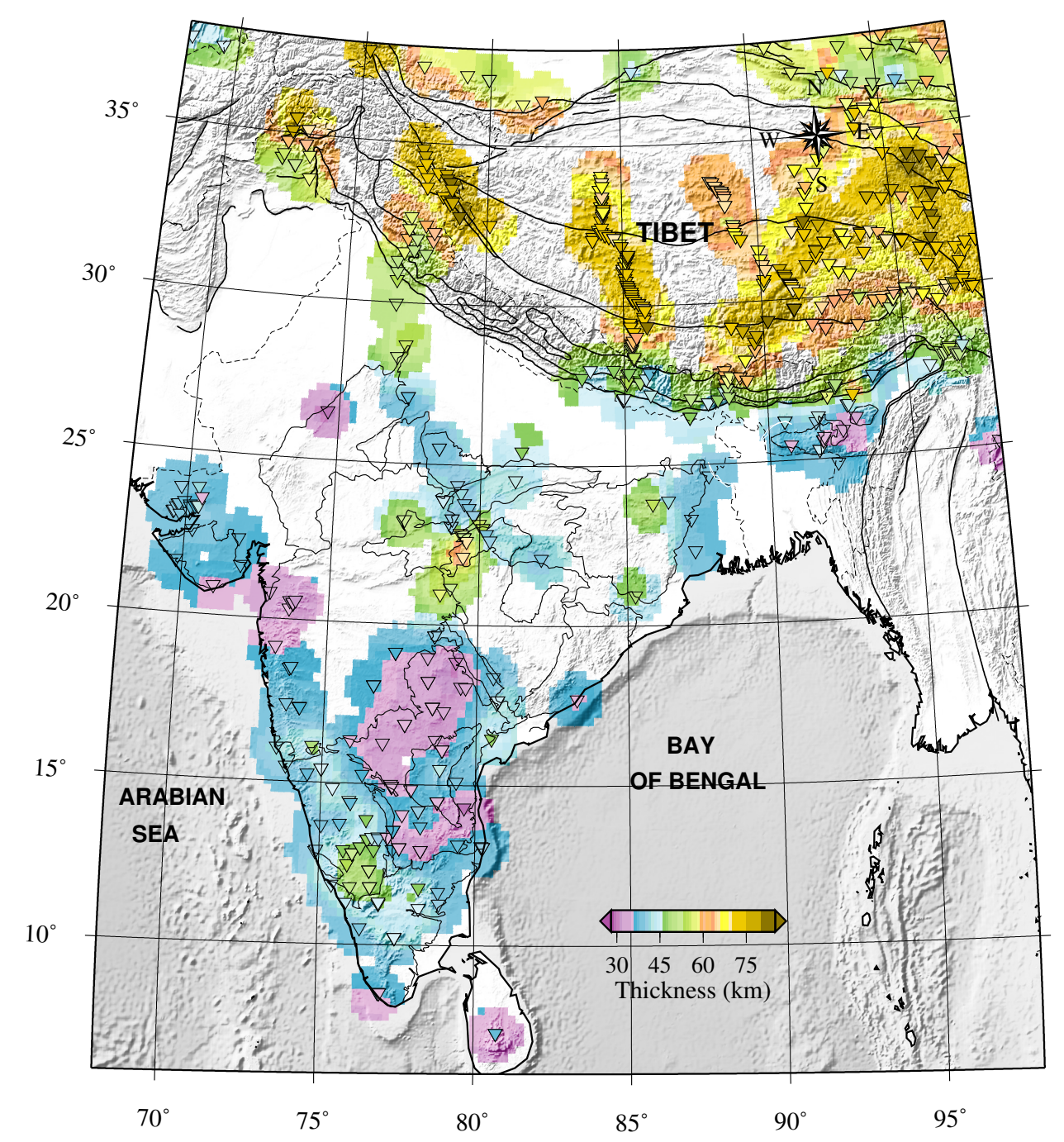

Figure 4: Crustal thickness map produced using estimates from receiver functions. A search radius of $100 \mathrm{~km}$ has been used to initialize the gridding with a nearest neighbour interpolation scheme, also employed in the subsequent figures. A total of 834 data points from 615 stations have been used to create the image. The location of the broadband seismic stations are marked by inverted triangles, colour coded by the original depth estimates.. The data sets for the Indian region are from Saul et al. (2000); Kumar et al. (2001); Sarkar et al. (2003); Gupta et al. (2003); Kumar et al. (2004); Rai et al. (2003, 2005); Mitra et al. (2005); Tiwari et al. (2006); Pathak et al. (2006); Mitra et al. (2008); Jagadeesh and Rai (2008); Julià et al. (2009); Rai et al. (2009a); Singh et al. (2010); Acton et al. (2011); Kayal et al. (2011); Singh et al. (2012); Hazarika et al. (2013a); Borah et al. (2014a); Kumar and Mohan (2014); Li et al. (2014); Mandal (2012); Vinnik et al. (2007), supplemented by results from Tibet ((Sherrington et al., 2004) and (Li et al., 2014) and references therein).Figure 4 employs data points from broadband receiver functions, and the crustal surface is interpolated using a search radius of $100 \mathrm{~km}$. 


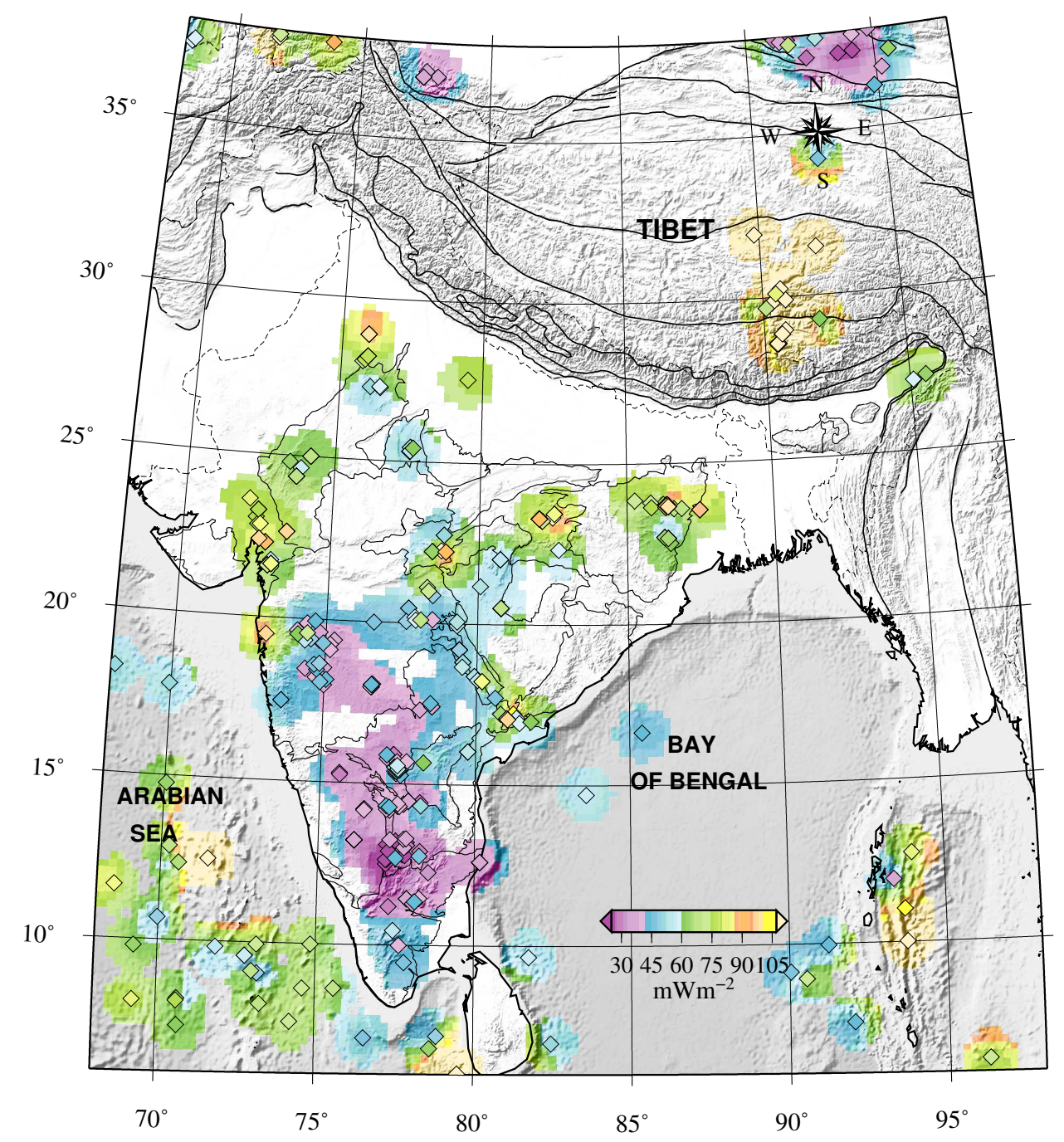

Figure 5: Heat flow values taken from the global heat flow data base of the International Heat Flow Commission (http://www.heatflow.und.edu). with additional values from Nagaraju et al. (2012). The individual data points are shown by diamonds. Heat flow data from 112 observations have been used to create the map, with the same interpolation scheme as used for crust (Figure 4) 

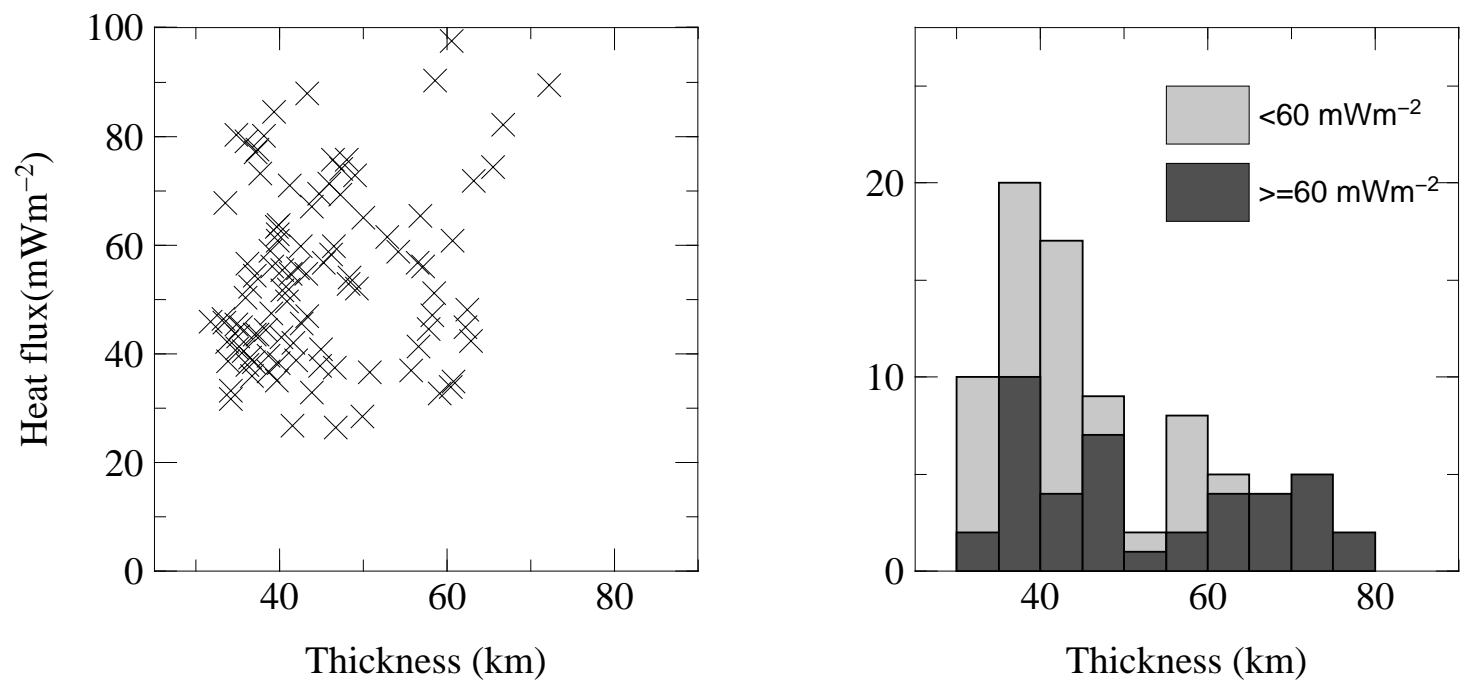

Figure 6: Heat flow vs crustal thickness for the Indian region (left panel). The values are extracted at common nodes for which both heat flow and crustal thickness estimates are available, interpolated at $1 \times 1^{\circ}$. The histogram in the right panel shows heat flow estimates at particular nodes split into two regimes, $<60$ and $\geq 60 \mathrm{mWm}^{-2}$. 


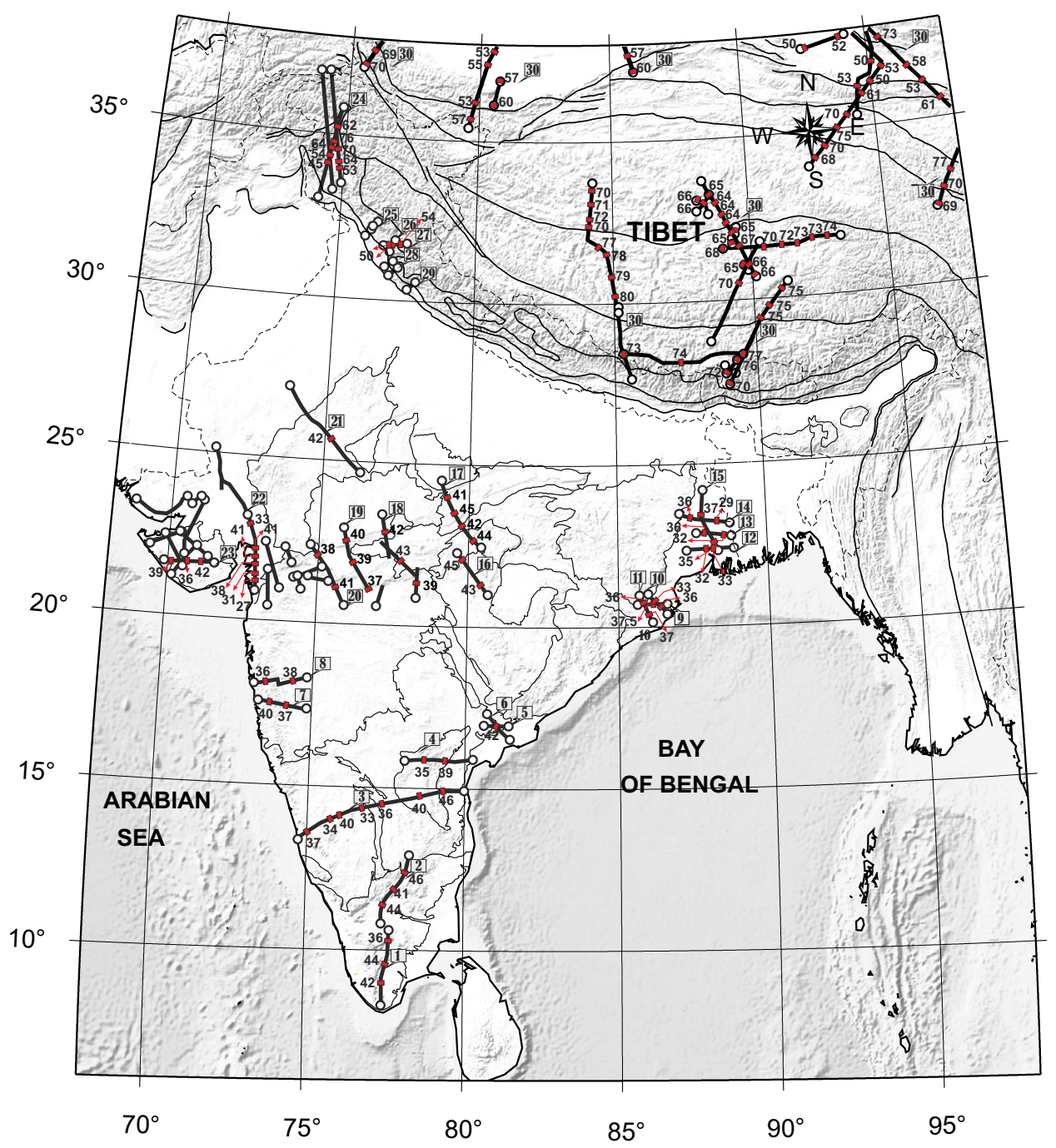

Figure 7: Deep seismic sounding profiles over various geological provinces of the India regions. The crustal thickness values picked along profiles are shown by red rectangles at their actual position. The same values have been used to make the crustal image in Figure 7. The profile end points are shown by white circles. 1: Behera (2011); 2:Reddy and Rao (2003); 3:Kaila et al. (1979); 4:Kaila et al. (1987); 5:Kaila et al. (1990); 6:Kaila et al. (1990); 7:Kaila et al. (1981c); 8:Kaila et al. (1981c); 9:Behera et al. (2004); 10:Behera et al. (2004); 11:Behera et al. (2004); 12:Kaila et al. (1992); 13:Rao et al. (1999); 14:Kaila et al. (1992); 15:Rao et al. (1999); 16:Reddy et al. (2000); 17:Murty et al. (2008); 18:Kaila and Rao (1986); 19:Kaila et al. (1985); 20:Kaila et al. (1989); 21:Prasad and Rao (2006); 22:Kaila et al. (1981a); 23:Kaila et al. (1981b); 24:Kaila (1981); 25:Powers et al. (1998); 26:Prasad et al. (2011); 27:Prasad et al. (2011); 28:Powers (1996); 29:Powers et al. (1998); 30:Xiaosong et al. (2009) and references therein. 


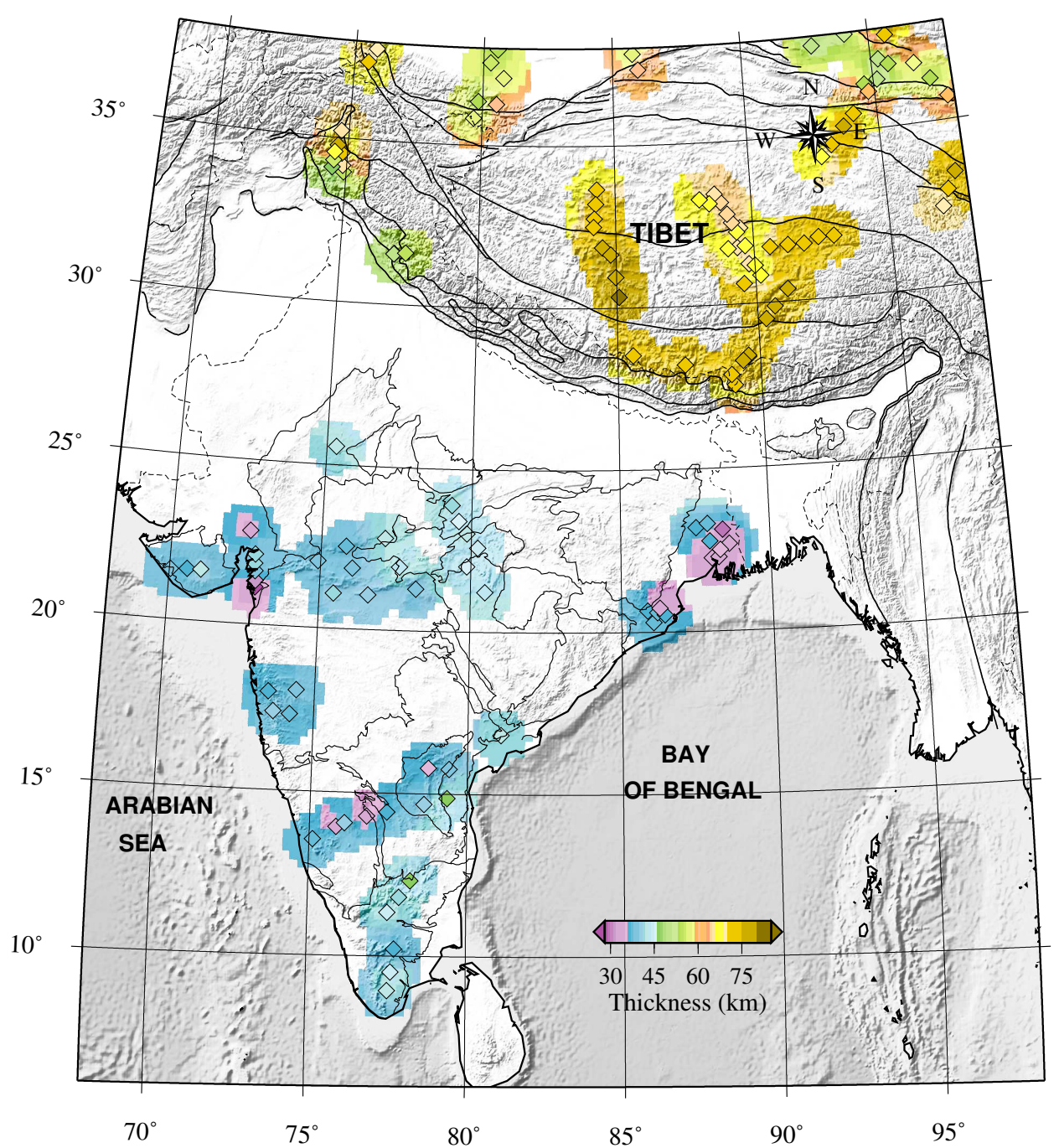

Figure 8: Map of crustal thickness, using published results from deep seismic sounding. 

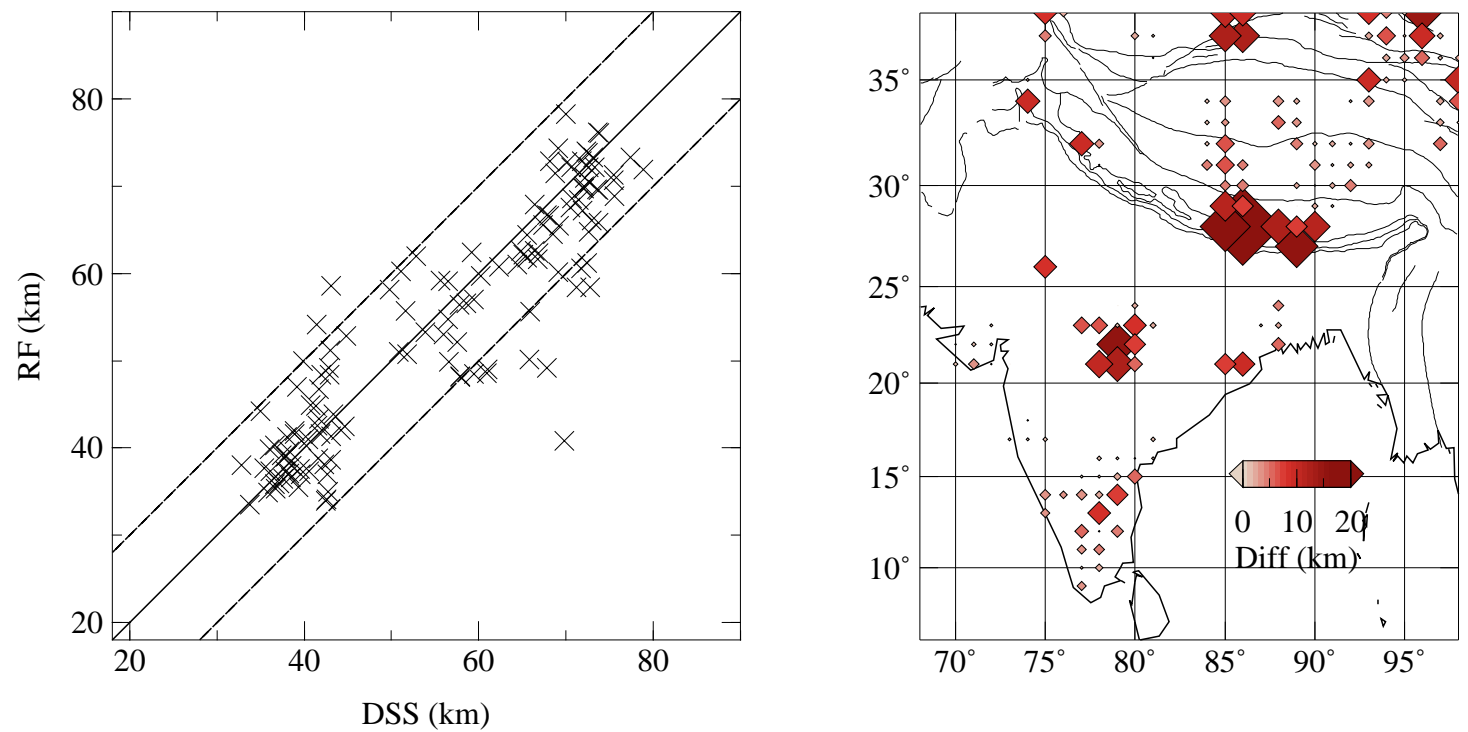

Figure 9: Correlation of crustal thickness estimates from Deep Seismic Sounding (DSS) vs $\mathrm{RF}$ (receiver functions) (left panel). Values are extracted at common nodes for which both crustal depth estimates are available, interpolated at $1 \times 1^{\circ}$. In the right panel the differences are plotted at particular node points, where color and symbol both represents the difference in the depth estimates. 


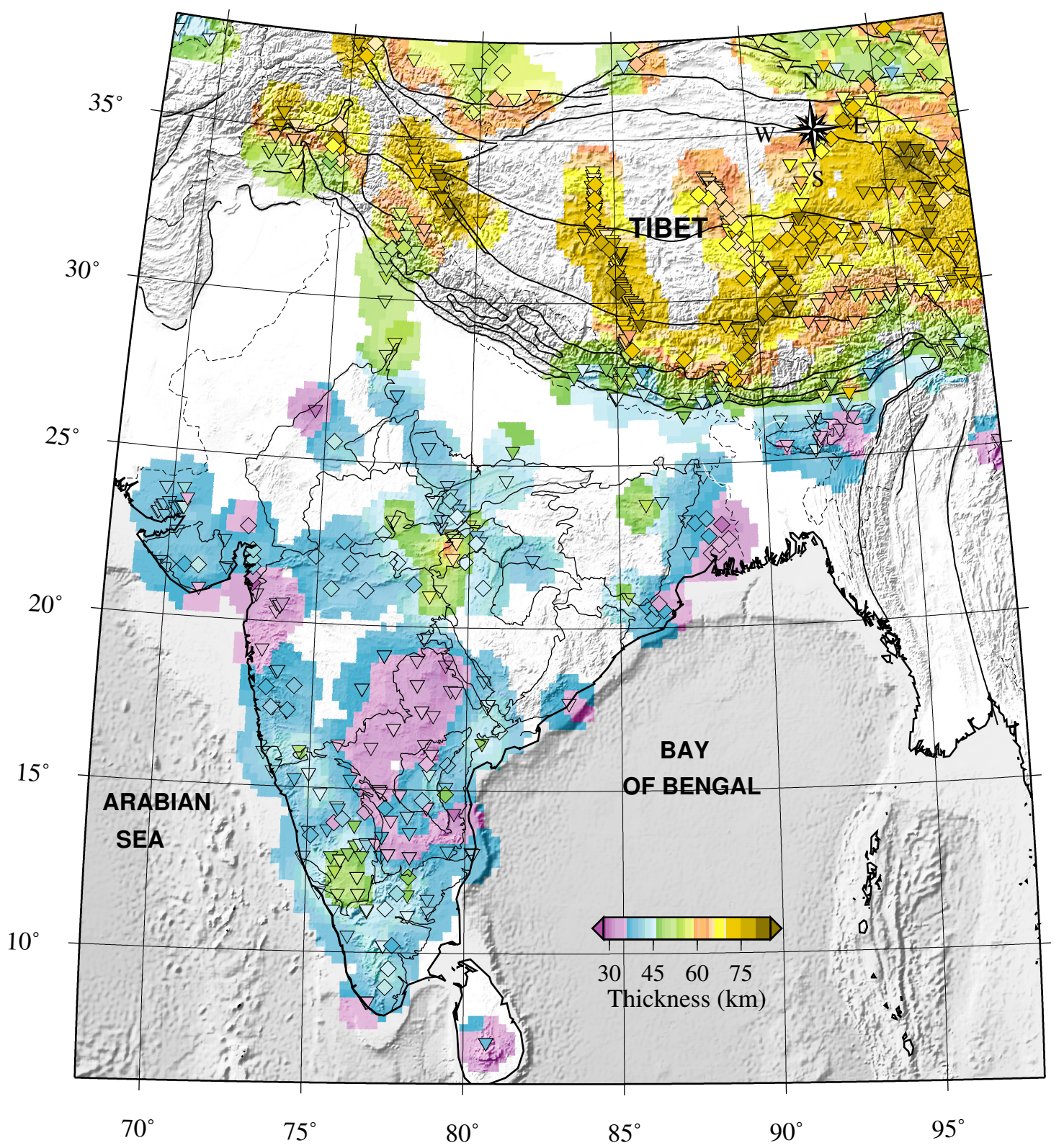

Figure 10: Map of crustal thickness combining all available information from receiver functions and Deep Seismic Sounding. 


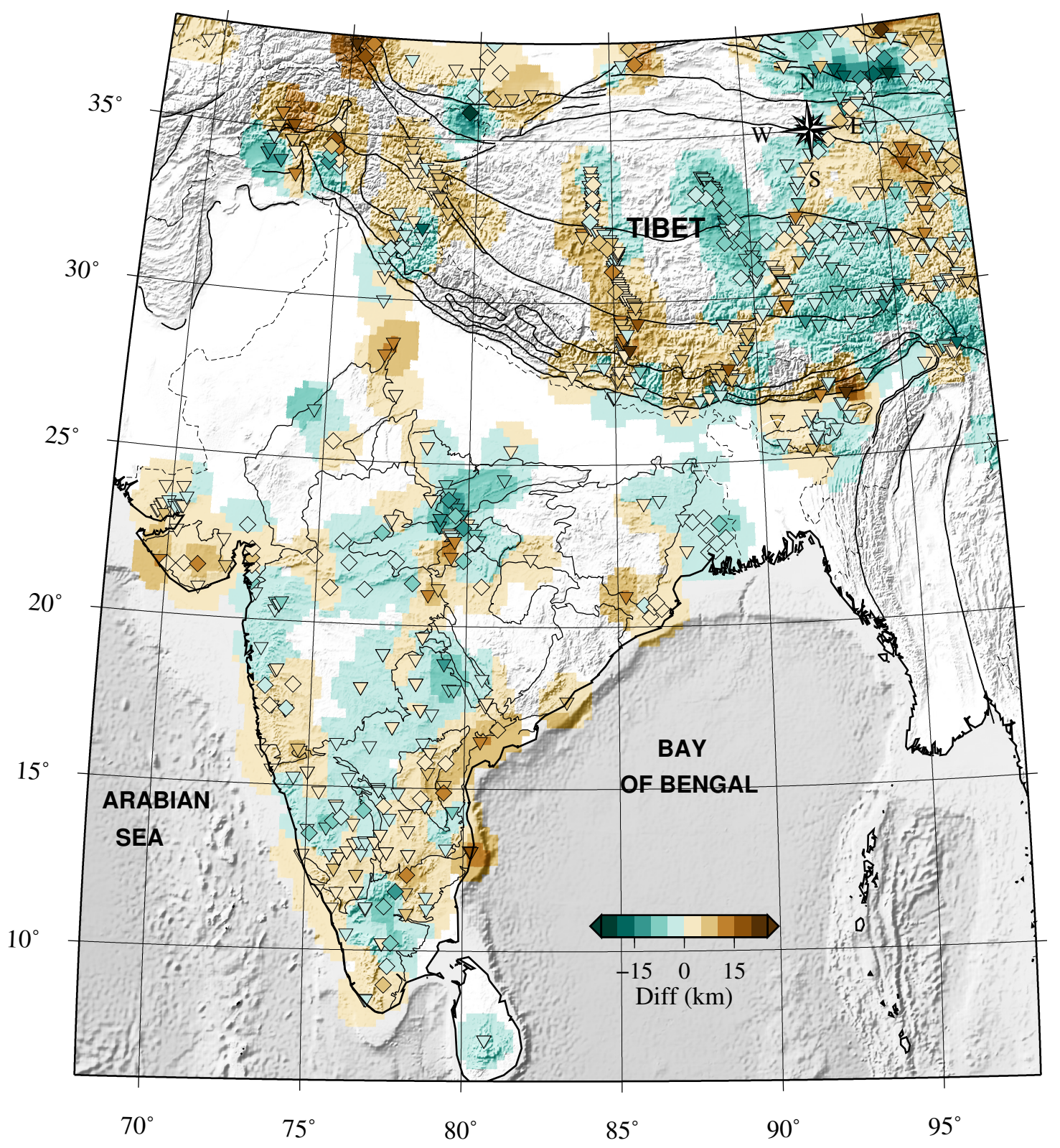

Figure 11: The difference in thickness obtained from CRUST1.0 Laske et al. (2013) and using data from receiver functions and Deep Seismic Sounding. The negative and postive values show thin and thick crust respectively with respect to CRUST1.0. 

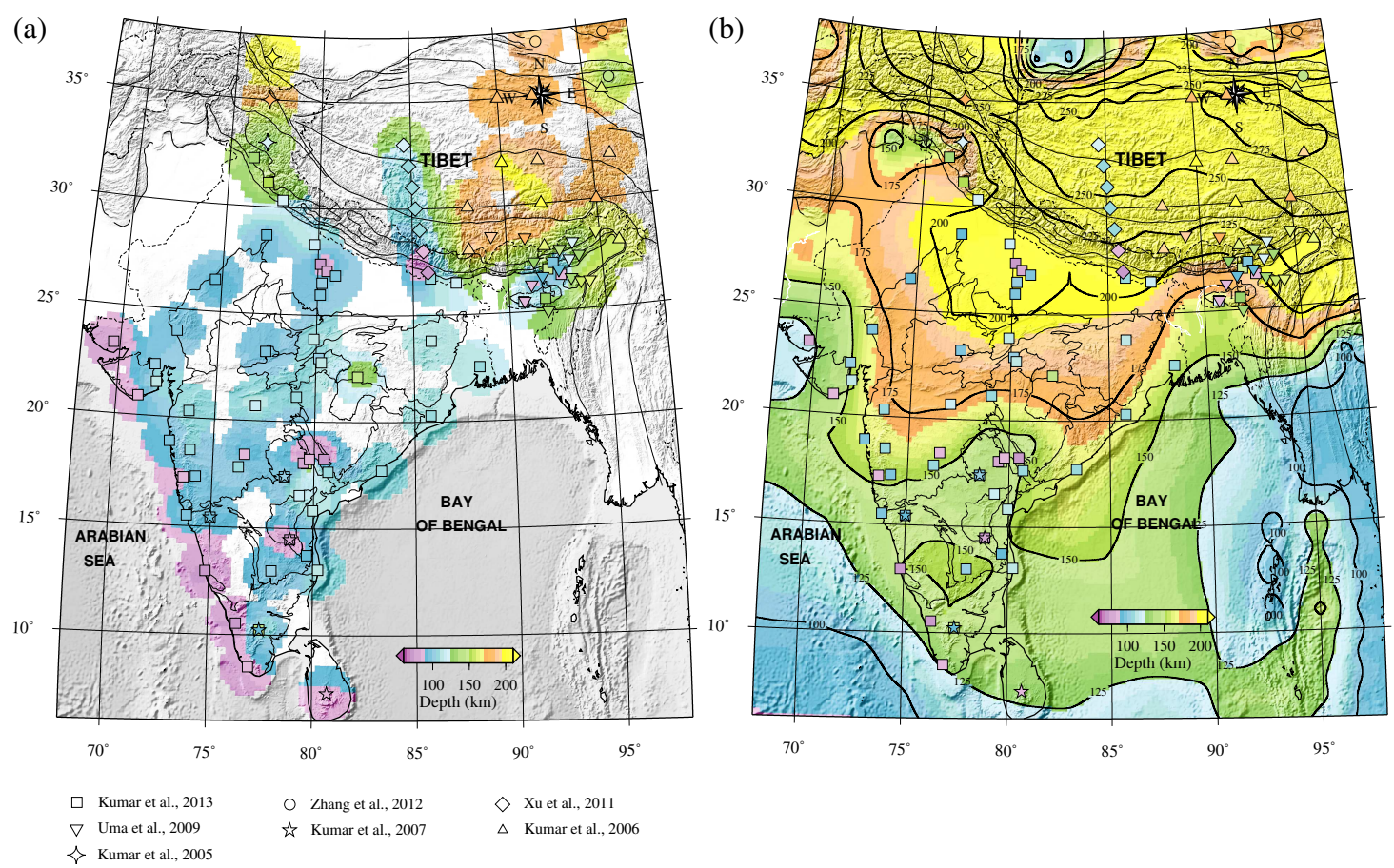

Figure 12: (a) The lithospheric thickness estimates as observed in various receiver functions studies (Kumar et al. (2007); Oreshin et al. (2008); Patro and Sarma (2009); Rychert and Shearer (2009); Ramesh et al. (2010); Devi et al. (2011). (b) lithospheric thickness estimates from surface wave tomography (Priestley and McKenzie, 2013). 

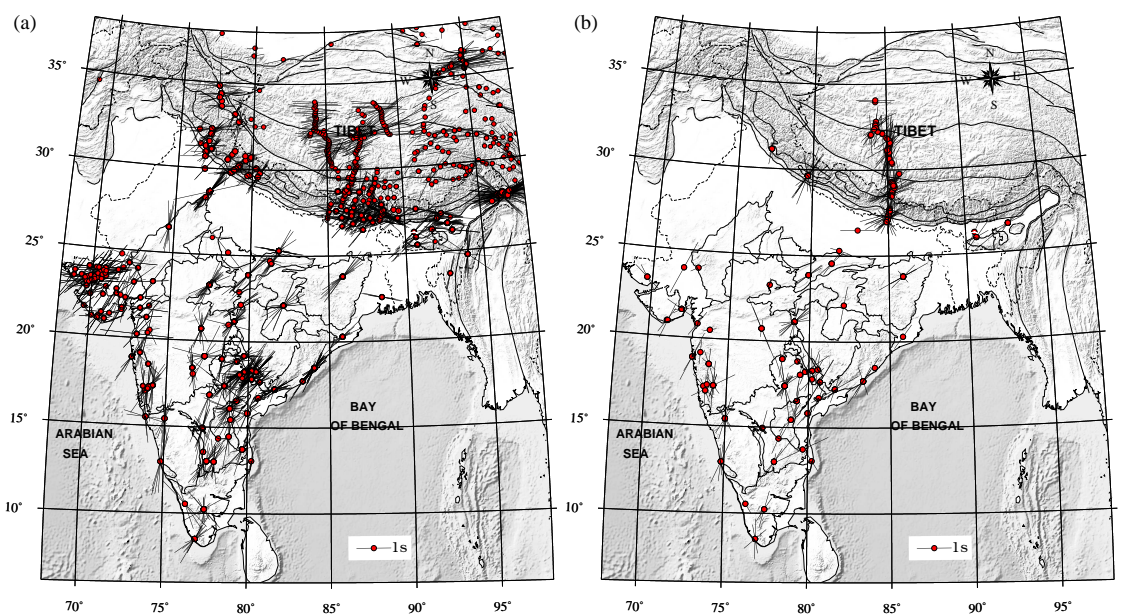

Figure 13: Individual shear wave splitting observations: (a) SKS/SKKS waves: Singh et al. (2006) - northeast Himalaya; Singh et al. (2007) - Sikkim Himalaya; Kumar and Singh (2008) - Indian shield; Oreshin et al. (2008) - western Himalaya; Heintz et al. (2009) - Indian shield; Kumar et al. (2010) - Godavari Graben; Mandal (2011) - northwest India; Madhusudhan Rao et al. (2013) - northwest Deccan Volcanic Province and Hazarika et al. (2013b) - northeast India (b) direct-S waves: Roy et al. (2012) - eastern Dharwar craton;Saikia et al. (2010) Indian shield. The splitting results for Tibet are taken from the compilations of Wüstefeld et al. (2008). 

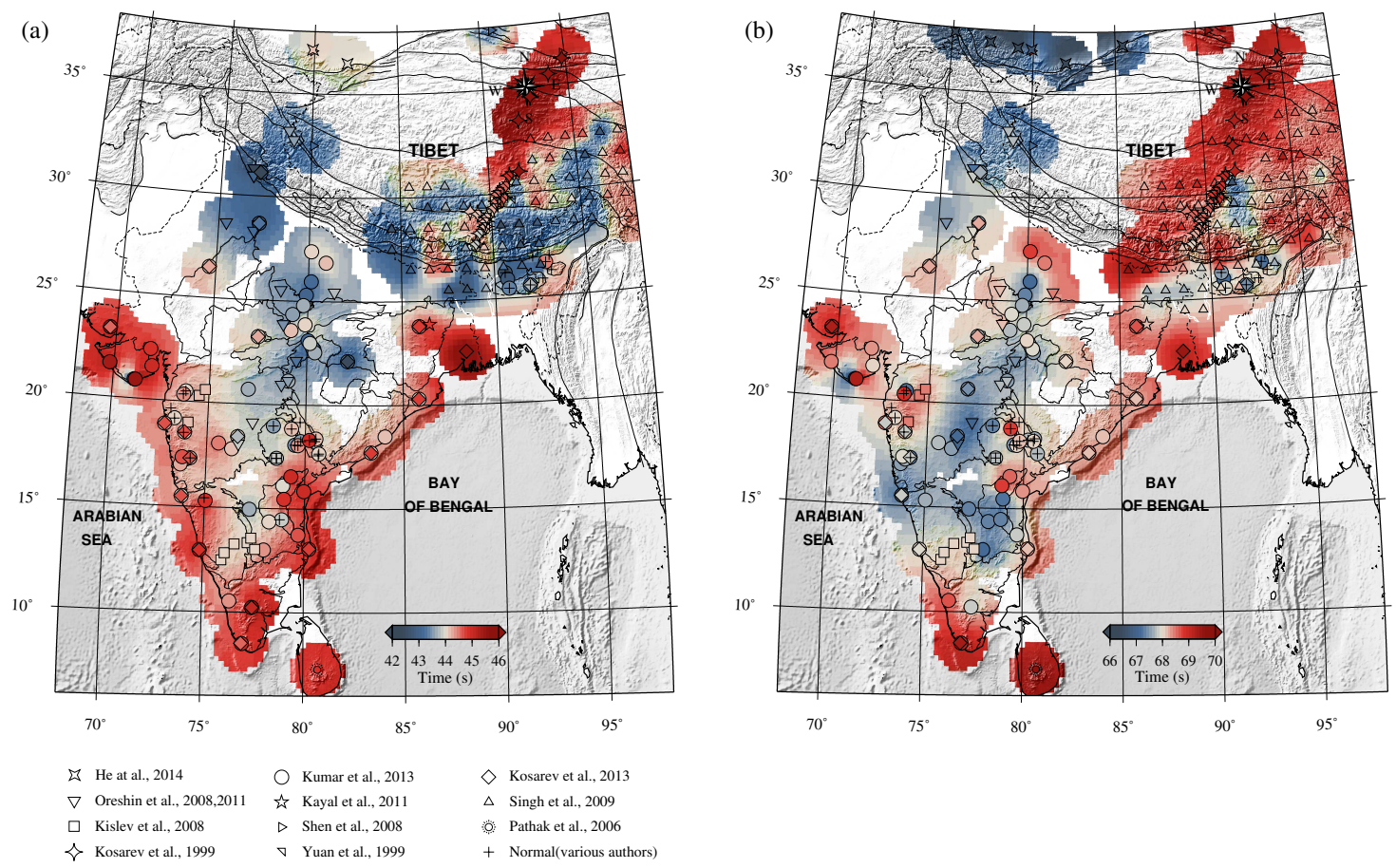

Figure 14: (a) The vertical passage time of seismic $\mathrm{P}$ waves to the $410 \mathrm{~km}$ discontinuity as reported by various studies: He et al. (2014); Kumar et al. (2013a); Kosarev et al. (2013); Oreshin et al. (2011, 2008); Kayal et al. (2011); Singh and Kumar (2009); Kiselev et al. (2008); Shen et al. (2008); Pathak et al. (2006); Kosarev et al. (1999); Yuan et al. (1997). Different symbols are used to indicate each set of results. The results of Rai et al. (2009b) are not shown here for consistency, as they are based on piercing points over very large areas. The normal behaviour for $410(+)$ is seen in the studies by Saul et al. (2000); Ramesh et al. (2005); Kumar and Mohan (2005); Singh et al. (2012); Sharma and Ramesh (2013). (b) same as a) for $660 \mathrm{~km}$ discontinuity. The only exception is the $660 \mathrm{~km}$ discontinuity reported by Sharma and Ramesh (2013) which is not plotted due to its sporadic nature. 